\title{
Are press depictions of Affordable Care Act beneficiaries favorable to policy durability?
}

Jacqueline Chattopadhyay, University of North Carolina at Charlotte

ABSTRACT. Background: If successfully implemented and enduring, the Affordable Care Act (ACA) stands to expand health insurance access in absolute terms, reduce inter-group disparities in that access, and reduce exposure to the financial vulnerabilities illness entails. Its durability-meaning both avoidance of outright retrenchment and fidelity to its policy aims-is thus of scholarly interest. Past literature suggests that social constructions of a policy's beneficiaries may impact durability.

Questions: This paper first describes media portrayals of ACA beneficiaries with an eye toward answering three descriptive questions: (1) Do portrayals depict beneficiaries as economically heterogeneous? (2) Do portrayals focus attention on groups that have acquired new political relevance due to the ACA, such as young adults? (3) What themes that have served as messages about beneficiary "deservingness" in past social policy are most frequent in ACA beneficiary portrayals? The paper then assesses how the portrayal patterns that these questions uncover may work both for and against the ACA's durability, finding reasons for confidence as well as caution.

Methods: Using manual and automated methods, this paper analyzes newspaper text from August 2013 through January 2014 to trace portrayals of two ACA “target populations" before and during the new law's first open-enrollment period: those newly eligible for Medicaid, and those eligible for subsidies to assist in the purchase of private health insurance under the ACA. This paper also studies newspaper text portrayals of two groups informally crafted by the ACA in this timeframe: those gaining health insurance and those losing it.

Results: The text data uncover the following answers to the three descriptive questions for the timeframe studied: (1) Portrayals may underplay beneficiaries' economic heterogeneity. (2) Portrayals pay little attention to young adults. (3) Portrayals emphasize themes of workforce participation, economic self-sufficiency, and insider status. Health status, age, gender, and race/ethnicity appear to receive little attention.

Implications and Conclusions: Existing literature suggests that these portrayal patterns may both support and limit ACA durability. In favor of durability is that ACA beneficiaries are depicted in terms that have been associated with deservingness in past American social policy-particularly being cast as workers and insiders. Yet, the results also give three reasons for caution. First, ACA insurance-losers are also portrayed as deserving. Second, it is unclear how the portrayal patterns found may impact the durability of the ACA's efforts to cut insurance disparities by age, health status, and especially race/ethnicity. Third, portrayals' strong casting of beneficiaries as workers, and limited attention to beneficiaries' economic heterogeneity and to young adults, may do little to help cultivate beneficiary political engagement around the ACA.

Key words: Social constructions, target populations, policy feedback, Affordable Care Act, media portrayals

\section{Introduction}

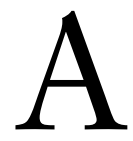

$s$ the "first national effort to ensure access [to health insurance] to the nonelderly population," 1 the Affordable Care Act (ACA)

doi: $10.1017 /$ pls.2015.16

Correspondence: Department of Political Science and Public Administration, University of North Carolina at Charlotte, 9201 University City Blvd., Charlotte, NC 28223. Email: jchattop@uncc.edu may well be "the largest change in social welfare policy since the Great Society and perhaps the New Deal."2 Among its aims are insuring a large share of the uninsured, ${ }^{3}$ cutting insurance disparities along the lines of health status, ${ }^{4}$ age,${ }^{5}$ and race/ethnicity, ${ }^{6,7}$ and reducing households' exposure to the financial vulnerabilities that illness entails. ${ }^{8,9}$ Thus, there is much to motivate research into the ACA's potential for "durability"10_ 


\section{Chattopadhyay}

meaning both its avoidance of outright retrenchment, ${ }^{11}$ and fidelity to its policy aims over time. ${ }^{12}$

While some features of the ACA's "design" 13 may dispose it to reap "positive feedback processes," 14 as part II notes, other features may work against this prospect. Further, a policy's design is not the only determinant of its trajectory, ${ }^{15,16}$ and it is hardly certain the ACA will generate such feedbacks. ${ }^{17,18,19}$ As the ACA is implemented, it is surrounded by informal tools of political opportunity and challenge. ${ }^{20}$ How its beneficiaries are portrayed is one such tool.

Past research on American social policy indicates that portrayals of a policy's beneficiaries may relate to the responses the policy generates among those beneficiaries, the mass public, and political elites-actors all critical in policy implementation and durability. ${ }^{21}$ At the heart of much of this work is Schneider and Ingram's concept of the "social construction of target populations," meaning the "characterizations or popular images of the persons or groups whose behavior and well-being are affected by public policy." 22 Portrayals' dynamics are complex. Policies may enjoy political stability when portrayals help underscore beneficiaries' breadth, ${ }^{23,24}$ and "[a]rguments or images that spotlight social groups may activate stereotypes and prejudices" that "then become the dominant guideposts for the evaluation of public policy." 25 Simultaneously, policies curry strength and guard beneficiary interests when they encourage beneficiaries to see themselves as "politically meaningful" 26 groups, ${ }^{27,28,29}$ and may lack political endurance when this is not the case. ${ }^{30,31,32}$ Beneficiary mobilization is "not an automatic process," 33 and "[l] egislative achievements remain...p prone to being dismantled" 34 when intended beneficiaries have "barely offered more than tepid support." 35 Such dynamics may matter greatly to the ACA as a law forged amid partisan strife ${ }^{36}$ and repeatedly subject to Supreme Court scrutiny. Yet, no study to date has systematically described and analyzed ACA beneficiary portrayals. This paper does so. It first seeks descriptive answers to three questions about portrayals that the literature connects to policy durability: (1) Do portrayals depict ACA beneficiaries as economically heterogeneous? (2) Do portrayals focus attention on groups that have acquired new "political relevance" 37 due to the ACA? (3) What themes that have served as messages about beneficiary "deservingness" in past American social policy are most frequent in ACA beneficiary portrayals? It then assesses how the portrayal patterns uncovered in answering these questions may work for and against
ACA durability, finding reasons for confidence and caution.

Specifically, this paper reports on portrayals of two ACA "target populations" before and during the first four months of the ACA's first open enrollment period: those who are (or would be) newly eligible for Medicaid pending state expansion, and separately those eligible for the ACA's insurance subsidies. A focus on these groups is logical since two major ways that the ACA aims to cover the uninsured are by offering (1) Medicaid to people up to 133 percent ("effectively 138 percent" ${ }^{38}$ ) of the federal poverty level (FPL) who were not previously eligible for the program, and (2) subsidies to buy insurance to the uninsured at $100-400$ percent FPL. ${ }^{39}$ While not the only means by which the ACA addresses uninsurance, these two mechanisms' importance is underscored by their discussion among academics, ${ }^{40}$ research institutes, ${ }^{41,42,43}$ and courts, ${ }^{44,45}$ by the striking cross-state (and cross-time) variation in Medicaid expansion and exchange facilitation arrangements (see Table 1), ${ }^{46,47,48,49}$ and by their inter-dependence. ${ }^{50}$

This paper also reports on portrayals of two groups informally crafted by the ACA in this period: those gaining health insurance (insurance-gainers) due to the ACA, and those losing it (insurance-losers). The latter emerged as a category during HealthCare.gov's rollout, as well illustrated by a document entitled "Because of Obamacare... I Lost My Insurance" that circulated among ACA opponents in Congress in November 2013. ${ }^{51}$ For brevity, this paper refers to the newly Medicaid-eligible, subsidy-eligible, and insurancegainers collectively as ACA "beneficiaries," in the sense used by others. ${ }^{52}$

The portrayals reported come from an original dataset of newspaper article text applicable at the state level from August 1, 2013 through January 31, 2014, gathered retroactively on February 3, 2014. (Citations for the newspaper articles used to build this paper's data are not included in the bibliography but are available by request). The ACA's first open-enrollment period officially ran October 1, 2013 to March 31, 2014, with a brief Special Enrollment Period thereafter. ${ }^{53}$ The data thus begin two months before, and run four months into, this first open enrollment period. For this reason and others that part IV notes, the timeframe studied is a critical one in the ACA's implementation.

To preview the results, the data suggest that portrayals underplay beneficiaries' economic heterogeneity, pay little attention to young adults-a key group the 


\section{Press depictions of ACA beneficiaries}

Table 1. State Medicaid expansion and exchange decisions as of fourth quarter 2015.

\begin{tabular}{|c|c|c|c|c|c|}
\hline State & Expand Medicaid & Exchange type & State & Expand Medicaid & Exchange type \\
\hline Alabama & no & federally facilitated & Montana & yes & federally facilitated \\
\hline Alaska & yes & federally facilitated & Nebraska & no & federally facilitated \\
\hline Arizona & yes & federally facilitated & Nevada & yes & state run, fed. assist \\
\hline Arkansas & yes & partnership & New Hampshire & yes & partnership \\
\hline California & yes & state run & New Jersey & yes & federally facilitated \\
\hline Colorado & yes & state run & New Mexico & yes & state run, fed. assist \\
\hline Connecticut & yes & state run & New York & yes & state run \\
\hline Delaware & yes & partnership & North Carolina & no & federally facilitated \\
\hline Florida & no & federally facilitated & North Dakota & yes & federally facilitated \\
\hline Georgia & no & federally facilitated & Ohio & yes & federally facilitated \\
\hline Hawaii & yes & state run, fed. assist & Oklahoma & no & federally facilitated \\
\hline Idaho & no & state run, fed. assist & Oregon & yes & state run, fed. assist \\
\hline Illinois & yes & partnership & Pennsylvania & yes & federally facilitated \\
\hline Indiana & yes & federally facilitated & Rhode Island & yes & state run \\
\hline Iowa & yes & partnership & South Carolina & no & federally facilitated \\
\hline Kansas & no & federally facilitated & South Dakota & no & federally facilitated \\
\hline Kentucky & yes & state run & Tennessee & no & federally facilitated \\
\hline Louisiana & no & federally facilitated & Texas & no & federally facilitated \\
\hline Maine & no & federally facilitated & Utah & debate & fed. indiv. state SHOP \\
\hline Maryland & yes & state run & Vermont & yes & state run \\
\hline Massachusetts & yes & state run & Virginia & no & federally facilitated \\
\hline Michigan & yes & partnership & Washington & yes & state run \\
\hline Minnesota & yes & state run & West Virginia & yes & partnership \\
\hline Mississippi & no & fed. indiv. state SHOP & Wisconsin & no & federally facilitated \\
\hline Missouri & no & federally facilitated & Wyoming & no & federally facilitated \\
\hline
\end{tabular}

Note: Medicaid decision data in this table are from http://kff.org/health-reform/state-indicator/state-decisions-for-creating-health-insurance-e xchanges-and-expanding-medicaid/ and are as of November 2, 2015. This KFF webpage also provides data on exchange arrangements, but exchange data in this table are from page 56 of the report at http://www.ncsl.org/portals/1/documents/health/health_insurance_exchanges_st ate_profiles.pdf, and are as of October 20,2015. While assembling the newspaper text data for this article, the author referred to Medicaid expansion decision data from June 2014 from http://kaiserfamilyfoundation.files.wordpress.com/2014/03/current-status-of-the-medicaid-exp ansion-decisions-healthreform1.png, and exchange arrangement decision data from May 2014 that were available on page 56 of the report previously found at http://www.ncsl.org/Portals/1/Documents/Health/Health_Insurance_Exchanges_State_Profiles.pdf.

ACA makes politically relevant—and emphasize themes of workforce participation, economic self-sufficiency, and insider status, giving little attention to health status, age, gender, and race/ethnicity. These three descriptive findings-assessed through the lens of existing literature-suggest reasons for both expectancy and caution regarding the ACA's durability. Favoring durability is the finding that beneficiaries are depicted in terms associated with deservingness in past American social policy-particularly being cast as workers and insiders. Yet, there are three broad reasons for caution. First, ACA insurance-losers are also portrayed as deserving. Second, it is unclear how the portrayal patterns found may impact the durability of the ACA's efforts to cut insurance disparities by age, health status, and especially race/ethnicity. Third, portrayals' strong casting of beneficiaries as workers, and limited attention to beneficiaries' economic heterogeneity and to young adults, may do little to help the ACA cultivate beneficiaries' political engagement.

\section{Background: motivations and foundational literature}

A key part of the ACA's design that may support durability is that it is in many ways what Skocpol terms a "[c]ross-[c]lass [s]ocial [p]olic[y]." others ${ }^{55,56,57}$ note that the ACA is a "[r]edistributive [r]eform" 58 in granting "subsides to millions of working people of modest means." ${ }^{, 59}$ It also includes features focused on cutting disparities. ${ }^{60,61}$ Simultaneously, subsidies go to middle-income earners. ${ }^{62,63}$ President Obama has appealed to the mass public for "'help in spreading the word" on how the ACA "can make a difference in your lives and the lives of your families," 64 and the ACA by some estimates may benefit the "vast majority of Americans." 65 Cross-class policies tend to enjoy notable spans of political success. ${ }^{66,67}$ They are administered in non-stigmatizing ways, ${ }^{68,69}$ foster political participation by beneficiaries of all income levels, ${ }^{70}$ and arrange at least latent coalitions of low- and middle-income earners. ${ }^{71,72}$ Scholars argue that the latter's stake as beneficiaries bolsters Social 


\section{Chattopadhyay}

Security, ${ }^{73,74}$ Medicare, ${ }^{75}$ and Medicaid. ${ }^{76}$ Neckerman, Aponte, and Wilson argue that programs "available to working- and middle-class segments of society as well as to the poor, are more likely to attract political support, and therefore more generous and stable funding." 77 Greenstein argues that policies are politically stronger when-like the ACA in some respects-they "do not separate those modestly above the poverty line from those well below it" but rather "combine these two groups." 78

Yet, another part of the ACA's design may work against beneficiary mobilization and mass support: many of its benefits are what Mettler calls "submerged."79 Unlike Social Security, whose "stakes are high and clear," 80 submerged benefits "leave much of the public, even beneficiaries themselves, unaware of government's role, incognizant of... what is at stake... and unengaged and unlikely to take action." 81 Individuals' "awareness of government activity" is key in fostering positive policy feedbacks; ${ }^{82}$ but, "unlike visible policies that... attract group loyalty, policies of the submerged state are...too hidden...to generate such affiliations." ${ }^{83}$ Mettler notes that if a policy "neglects to reveal to citizens what government will do or has done on their behalf, it may....prove unsustainable, as opponents dismantle it or undermine implementation." 84 Mettler $^{85}$ and Patashnik and Zelizer ${ }^{86}$ explicitly worry that these concerns apply to the ACA.

Given these cross-cutting considerations, influences on the ACA's trajectory other than its design may be pivotal. Political context matters to policy durability. ${ }^{87}$ An informal but potent influence on a policy's course may reside in how beneficiaries are discussed and portrayed. ${ }^{88,89,90}$ Certainly, non-portrayal factors also matter, including political institutions, ${ }^{91,92,93}$ coalitions, ${ }^{94,95,96,97}$ "voluntary groups," 98 regional economies, ${ }^{99,100}$ and others articulated by Pierson, ${ }^{101}$ Greenstein, ${ }^{102}$ and Patashnik and Zelizer. ${ }^{103,104}$ Yet, as discussed below, portrayals relate to a policy's reception among intended beneficiaries, the mass public, and elites. And critically, portrayals may impact beneficiaries' participation in political institutions and coalitions, ${ }^{105,106,107}$ thus setting-like prior policies $\mathrm{do}^{108}$ - the terms on which these other influences on a policy's course operate. For all of these reasons, ACA beneficiary portrayals deserve study.

Portrayals also merit attention because three factors make the ACA vulnerable to the politics of target population constructions. First, the fact that the ACA is not universal, and does redistribute, makes it susceptible to a point made by Nelson and Kinder and echoed by Iyengar: 109 "[g]roup-centrism is pervasive" in American politics. ${ }^{110}$ "Many policies are...criticized on those grounds in public debate," 111 potentially influencing mass opinion on the policy. ${ }^{112}$ And, this criticism of policy can entail criticism of beneficiaries that discourages their program-specific and broader political participation. ${ }^{113}$

Second, scholars suggest that beneficiary portrayals can play a role in bringing about an eventual, and potentially bipartisan, unravelling of policies embraced by only one party. For instance, Soss, Fording, and Schram argue that "[f]rom the 1960s on, conservatives brandished the troubled lives of the poor as evidence of liberal [policy] failure and as a wedge issue,"114 and that parts of the 1996 Personal Responsibility and Work Opportunity Reconciliation Act responded to these portrayals, ${ }^{115}$ replacing Aid to Families with Dependent Children with Temporary Assistance for Needy Families. There are likely examples with the left's and right's roles reversed in other policy areas. The ACA has faced strong Republican challenge from inception, ${ }^{116,117,118}$ though the law also is not beloved by all Democrats. ${ }^{119}$ Skocpol and others argue that "no one... should think... the battle is over"120 simply because the ACA became law. ${ }^{121,122}$

Third, as explained below, benefit take-up may be sensitive to portrayals, and take-up is critical to the ACA's implementation. The possibility that "customers would not come" was a main concern of an executive branch official involved in implementing the ACA federal exchange. ${ }^{123}$ Low rates of Medicaid and subsidy take-up may especially hurt poorer states' economies, ${ }^{124}$ as these benefits are key routes by which the ACA stands to put money into states as others send it to the federal level. ${ }^{125,126,127,128}$ Thus, intended enrollees not taking up these benefits is arguably functionally akin to states leaving "money on the table." 129

A closer look at existing research unpacks how beneficiary portrayals may relate to a policy's reception by beneficiaries, the public, and elites; how portrayals may bear on people's thoughts about a policy; and why media portrayals are particularly important in these dynamics.

\section{Routes by which social constructions shape politics}

While it does not establish that portrayals are a causal "first mover," research including but not limited to Schneider and Ingram's finds portrayals linked to 


\section{Press depictions of ACA beneficiaries}

several phenomena that are important to a policy's durability. These phenomena include take-up of the policy's benefits, the policy's support in the mass public, the policy's treatment by political elites, and political participation by the policy's beneficiaries.

Portrayals may encourage or discourage take-up in two ways. First, alongside a policy's design and administration, beneficiary portrayals can signal whether a policy does or does not carry stigma. ${ }^{130}$ Stigma can lead those eligible for benefits to shun them. ${ }^{131,132,133}$ Citing Piven and Cloward, Neubeck and Cazenave in fact argue that public criticism of welfare recipients is aimed at eligible non-enrollees, who are thereby "discouraged from applying." 134 Second and simultaneously, beneficiary portrayals may be a piece of "political communication" that helps to "reveal what is at stake" where benefits are "submerged." 135 Beneficiary descriptions may help underscore self-interest in a policy. ${ }^{136}$ This informational role may be critical to take-up and broader beneficiary support, as a policy can collapse when people who are its intended beneficiaries do not believe themselves to be so. ${ }^{137,138}$

Portrayals may relate to a policy's popularity in the mass public, ${ }^{139,140}$ which forms opinions about policies partly by considering whom they benefit. ${ }^{141,142,143}$ "[S]ocietal support for...[a] program and its recipients" 144 gives elected officials "incentive to pay attention to" a program's beneficiaries, ${ }^{145}$ and can "set limits on"146 the scope of retrenchment proposals. ${ }^{147}$

Beneficiary portrayals may also relate to a program's popularity with lawmakers and thus alterations in its design and funding. ${ }^{148}$ While a "causal link between social constructions and policy designs is not inevitable," 149 Rose and Baumgartner find that "[t]he portrayal of the poor as either deserving or lazy drives public policy," specifically its "relative generosity... toward the poor." 150 In the past, temporary press portrayals of seniors as " greedy geezers" coincided with policymakers reassessing public spending on this typically favorably viewed group. ${ }^{151}$

Finally, portrayals can bear on a policy's durability by joining other factors in signaling beneficiaries about their political status. ${ }^{152,153,154}$ While again not proving causality, research supports Ingram and Schneider's hypothesis of a positive correlation between favorable portrayals and political participation. ${ }^{155,156}$ Beneficiaries of programs with favorably discussed target groups participate in politics at high rates, both in relation to the program and generally. ${ }^{157,158}$ For instance, seniors "defend their programs, warning lawmakers through their participation not to tamper with Social Security and Medicare."159 And, "because seniors are a politically dominant group, their preferences on other issues also matter. Policy effects spill over." 160 Recipients of programs whose beneficiaries are criticized do not, believing, as Soss and others ${ }^{161}$ note, that policymakers "do not understand, care about, or respond to 'people like them." "162 Participatory differences may owe partly to administrators' treatment of beneficiaries, ${ }^{163,164}$ which in turn may owe to administrators' several beliefs about beneficiaries. ${ }^{165}$ These dynamics well reflect Ingram and Schneider's argument that "social constructions of target groups...stimulate and advance the typifications, or cognitive models, carried along by institutions," 166 having "enormous influence upon citizenship roles, group mobilization, and civic participation." 167 To reiterate an earlier point then, portrayals may impact what Campbell calls "political inequality," 168 and thus the terms on which multiple other influences on a policy's path operate.

\section{Evidence that social constructions can operate on thoughts about policy}

Much of the preceding research on how social constructions matter in politics assumes, implicitly or explicitly, that social constructions operate on people's thoughts in policy relevant ways. The "framing effects" literature offers empirical support for this assumption. Druckman and Chong distinguish "frames in communication" from "frames in thought." $169,170,171$ Frames in thought concern "what an individual is thinking" while frames in communication are "what a speaker says (e.g., the aspects of an issue emphasized in elite discourse)." 172 Scholars use "framing" in both senses and explain their intersection. Nelson, Oxley, and Clawson's definition of framing as "the process by which a communication source constructs and defines a social or political issue for its audience," 173 and definitions given by others, ${ }^{174,175}$ well highlight how "frames in communication" may impact on "frames in thought." "If people can think about an issue... in multiple ways, they are susceptible to framing effects."176

Communication frames indeed matter in politics because they appear to impact frames in thought at least some of the time. Communication frames can "activate existing beliefs and cognitions." 177 For instance, Nelson and Kinder as noted find that "[a]rguments or images that spotlight social groups may activate stereotypes and prejudices," 178 an effect involving "emphasis frames" 179,180 that is also found by others. ${ }^{181,182,183,184}$ 


\section{Chattopadhyay}

Such effects can be sufficiently strong that, as Nelson and Kinder say, "[g]roup sentiments... become the dominant guideposts for the evaluation of public policy," 185 a point Jacoby also suggests. ${ }^{186}$ While "not inevitable," 187 elite-and arguably media-communication frames can encourage this outcome. ${ }^{188,189} \mathrm{Ja}$ coby notes that elites may undertake framing efforts with political goals in mind. ${ }^{190}$ Framing effects differ across people and contexts, ${ }^{191,192,193,194,195,196,197,198}$ but effects such as stereotype activation can happen even when listeners are politically sophisticated or disagree with the frame. ${ }^{199}$

Communication frames may also shape a policy's meaning to beneficiaries. For instance, Soss finds that " $[t]$ o many clients, news stories on welfare suggest that the degraded position they occupy in the program carries over to the rest of the polity. The stigmatizing discourse on welfare creates a bridge between their status as clients and... as citizens." 200 This article does not claim to uncover frames or framing effects of the sort reviewed here, or of other sorts. ${ }^{201,202}$ It aims simply to describe and analyze portrayals. But this literature suggests that if portrayals are seeds for communication frames, they could much influence the politics around the ACA.

\section{The relevance of social constructions from the mass media}

Schneider and Ingram identify the media as a key "carrier" of social constructions, ${ }^{203,204}$ and the media have perhaps a dominant role in shaping and disseminating claims about policy beneficiaries. ${ }^{205,206}$ But, the focus here on portrayals of beneficiaries in the media requires a defense from two possible objections. First, a large literature finds the media exerting "minimal effects" on public attitudes. ${ }^{207,208}$ Second, social constructions have other sources, including policy itself, 209,210,211 interactions of "policy, discourse, and the courts, $" 212$ and political elites. ${ }^{213}$

In response to the first objection, much research rejects minimal effects. Druckman suggests that studies of media communication have "cycled from maximal effects to minimal effects...to... indirect effects (i.e., agenda setting, priming, and framing)." ${ }^{214}$ Zaller argues that media effects are tough to detect statistically precisely because "mass communication... exercises... power on an essentially continuous basis." 215 Cook contends that, in the U.S., news media "directly influence political elites: helping to... shape the context of one legislator asking another for support." ${ }^{216}$ Cook's arguments potentially qualify Jacoby's indication that "frames typically originate with political leaders; the mass media serve as the "conduits." 217 Cook posits that media "news presents and interprets... [governmental] actions by means of agreed-upon production values." 218 And, Cook's assertion that the media are an institution with "shared processes and predictable products across news organizations" 219 tempers the concern that the "fragmented media environment" 220 of today "foreshadow[s] a return to... minimal effects." 221

In response to the second objection, constructions in other venues certainly matter. Yet, media frames may be more powerful than frames issued directly or only by, for instance, political elites. Iyengar, Peters, and Kinder, crediting Walter Lippmann, note that "media provide compelling descriptions of a public world that people cannot directly experience." 222 Others note that news is the "primary source of information that people have as distant events unfold," 223 and that media attention is "a key determinant of what makes it onto the public agenda." 224

These claims all suggest that the media are capableperhaps uniquely capable-of creating what Chong calls a "common frame of reference"- "an interpretation of an issue... popularized through discussion." 225 Iyengar argues that "mass media news presentations loom as powerful vehicles for political framing effects." 26 Nelson, Oxley, and Clawson make a similar point. ${ }^{227}$ Media portrayals may self-reinforce over time. ${ }^{228}$ DiAlto proposes that it is "discourse, perhaps most powerfully [supplied] by the mass media" that offers "rationale" for "[c]onstructions of deservedness and entitlement" in public policy. ${ }^{229}$ DiAlto, in fact, argues that "[s]ocial constructions of group identity" can be "generated and transmitted by the media in its capacity as a moral entrepreneur." 230 These messages reach the mass public and intended policy beneficiaries themselves. ${ }^{231}$ For all of these reasons, media portrayals of ACA beneficiaries are the focus here.

\section{Descriptive questions}

A vast range of social constructions merit study and could shape an analysis of target population portrayals. The analyses here do not start from hypotheses about the content of ACA beneficiary portrayals. Rather, the goal is to first objectively describe those portrayals, with an eye toward answering the three questions stated in the introduction, and then assess the possible pros and cons of the answers uncovered for durability. Existing 


\section{Press depictions of ACA beneficiaries}

literature explains how these three questions are useful in understanding portrayals' possible bearing on a policy's strength, and offers guidance for detecting the answers to these questions in textual portrayal data.

\section{Are ACA beneficiaries portrayed as economically het- erogeneous?}

As part II notes, a large set of scholarship argues that policies known to carry "cross-class" benefits enjoy broader mass support, ${ }^{232,233,234,235,236,237,238}$ and broader beneficiary political participation, ${ }^{239}$ than those appearing to benefit only poorer Americans. (And policies seen as narrowly benefitting the wealthy may also be unpopular. ${ }^{240}$ ) References to the range or mix of income levels to which a program gives benefits signal that a policy's beneficiaries are economically heterogeneous. ${ }^{241}$ Portrayals advancing the "political isolation of the poor... from the working and middle classes" would do the opposite. ${ }^{242}$

2. Do portrayals of beneficiaries highlight groups to which the ACA gives new political relevance?

Another question in the literature, and one highly relevant to the ACA, ${ }^{243}$ is whether a policy and the politics around it encourage beneficiaries to "identify themselves as [its] valued recipients." 244 Policies can "stimulat[e] brand new social identities and political capacities," 245 and gain political protection in the process, as documented in Campbell's study of how Social Security made seniors "[o]nce the age group least likely to participate in politics... the most active."246 "Without a government policy...there [wa]s no politically meaningful senior 'group." 247 But “[o]nce governmental benefits [we]re conferred on the basis of age... the group ha[d] political relevance and [wa]s ripe for mobilization by policy entrepreneurs, interest groups, and political parties." ${ }^{248}$ Similar potential exists in the ACA in several ways. ${ }^{249,250,251,252}$ To take one example, young adults may remain on parental insurance (if existent) up to age 26 under the ACA, ${ }^{253}$ and are coveted enrollees in the insurance options the ACA organizes. $^{254,255}$ While engaging this group is not-as part VIII discusses-the only way the ACA may "make citizens," 256 tracing mention of young adults is a start at gauging whether beneficiary portrayals are helping to foster newly "[p]oliticized social identities." 257

3. What themes that have served as messages about beneficiary "deservingness" in past social policy are most frequent in ACA beneficiary portrayals?

A question scholars have scrutinized for virtually all policies is whether beneficiaries are cast as "deserving" or "undeserving." $258,259,260,261$ Divisions between these categories "run like fault lines through the entire history of American social provision." 262 Policies whose beneficiaries are understood as deserving tend to be popular with the mass public, ${ }^{263}$ and those beneficiaries tend to exhibit "no moral qualms about defending the program." 264 Policies whose beneficiaries are constructed as undeserving tend to be unpopular with the mass public ${ }^{265}$ and beneficiaries themselves. ${ }^{266}$ Before this question can be broached for the ACA, however, it is necessary to answer a more preliminary one: what themes that have served as messages about beneficiary "deservingness" in the past are seen in ACA beneficiary portrayals?

Past research indicates that messages about deservingness may take the form of portrayals that associate beneficiaries with "social groups" 267 or "subgroups," 268 use "[p]ositive" or "[n]egative" constructions ${ }^{269}$ or stereotypes of those groups to deem them (un)deserving, and operate on mass, elite, and beneficiary attitudes through framing mechanisms. ${ }^{270}$ Citing Gordon, ${ }^{271}$ Soss, Fording, and Schram observe that "[e]valuations of deservingness [historically] fell along many dimensions... often rooted in differences of gender, race, ethnicity, and religion." 272 Alleged behaviors are another metric in evaluating deservingness. ${ }^{273}$ Past research indeed highlights several themes by which portrayals may send messages about deservingness.

One is through messages about whether beneficiaries engage in work and efforts toward selfsufficiency. Work strongly, perhaps centrally, ${ }^{274}$ distinguishes the deserving in American social policy. ${ }^{275,276,277,278,279,280,281}$ Thus, "citizens and taxpayers" are considered deserving, ${ }^{282}$ as are the "working poor." $283,284,285$ Schneider and Ingram's "[a]dvantaged" category consists of those who are favorably constructed and includes "business, science, the military, [and] the middle class." 286 Veterans are usually seen as deserving, ${ }^{287,288,289,290,291}$ as are those pursuing education. ${ }^{292,293}$ While "'the rich" and "Wall Street bankers" are often viewed unfavorably, ${ }^{294}$ customers or "clients"'295,296,297 in the economy are constructed favorably. Especially in neoliberalism, the "competent and self-reliant market actor-working, investing, choosing, and assessing returns-is... synonymous with the good citizen." 298 Those unable to "look out for their own interests" 299 or achieve "economic selfreliance" 300 are cast as the opposite. Indeed, Americans across the income distribution often see welfare recipients as undeserving, ${ }^{301,302,303,304}$ along with 


\section{Chattopadhyay}

the non-working "nonelderly, nondisabled poor,"305 criminals, ${ }^{306}$ and those with "vicious habits" 307 such as alcohol or drug use ${ }^{308}$ — believed to self-inflict dependency. 309

Whether beneficiaries are "insiders" or "outsiders" has also served as a signal of deservingness, with "ingroups" being considered deserving. ${ }^{310}$ (Soss, Fording, and Schram in fact suggest that the "line between community members and 'outsiders" historically formed a "moral distinction" alongside deservingness, drawn between people. ${ }^{311}$ ) Certain words or phrases can convey assertions about whether beneficiaries are "insiders." Winter notes that use of the "first person" and phrases like "our elderly" by elites discussing a policy signals that beneficiaries are "ingroups," 312 as do comments associating the policy with "everyone," the "national good," and referencing “"Americans...pull[ing] together for the common good." 313 Ono and Sloop make similar observations about words such as "Californians" in newspapers in some circumstances. ${ }^{314}$ While this article studies media remarks, Winter's notes on the language of elected officials, and Ono and Sloop's insights, are instructive in explaining one way to track references to "insider" status in the portrayal data.

Race is a uniquely strong cue in American politics, ${ }^{315,316}$ and one that may be invoked obliquely. $317,318,319$ Schneider and Ingram observe that racial and ethnic minorities have frequently been negatively constructed ${ }^{320}$ as compared to Americans of European origin. ${ }^{321}$ Other scholarship gives examples of these constructions, ${ }^{322,323,324,325}$ and research finds beliefs about beneficiary race or ethnicity often twined with beliefs about whether benefits are deserved-a pattern that scholars have interpreted as evidence of "symbolic racism,"326 "racial resentment," 327 and "welfare racism." 328 Winter finds favorability to Social Security as an "earned" benefit linked not so much to its universalism but its association with "whiteness."329 Gilens and others present evidence that opposition to welfare is rooted in an interaction of negative racial stereotypes with beliefs that African Americans are beneficiaries. ${ }^{330,331,332}$ Soss, Fording, and Schram report that welfare is more punitive where many beneficiaries are racial minorities. ${ }^{333}$ Asian Americans, ${ }^{334}$ Latinos, ${ }^{335}$ and immigrants ${ }^{336,337,338}$ have often been defined as undeserving in being defined as "foreigners"339 or "outsiders." Soss, Fording, and Schram's "Racial Classification Model" 340 posits that "race can operate below the level of conscious reflec- tion"341 as a "mental structure" 342 in all individuals' beliefs and decisions. ${ }^{343}$ In researching race and policy, it is important to study "how minorities are portrayed," 344 and the many "implicit" forms racial references can take. ${ }^{345,346,347,348}$ Such analysis is, however, beyond the methodology of the present article. As a start at preliminarily assessing whether race/ethnicity is salient in ACA portrayals, this article tracks the frequency of explicit references. (See the Appendix for a detailed methodological explanation.)

Portrayals of beneficiary gender have also carried implications about deservingness in U.S. social policy. Public assistance beneficiaries may be seen more sympathetically when female. ${ }^{349,350}$ The United States once "came close to forging a maternalist welfare state" dedicated to "help[ing] adult American women as mothers or as potential mothers,"351 and mothers tend to be positively constructed. ${ }^{352}$ In contrast, "able-bodied" men on public assistance are especially considered to be the "unworthy' poor." 353 That said, women's somewhat more favorable treatment in social policy is historically more typical for white than non-white women, ${ }^{354,355,356,357,358}$ middle and upper income than poor women, ${ }^{359}$ and married than unmarried mothers. ${ }^{360,361,362}$ Thus, it is relevant to track women's prevalence, and references to motherhood and families, in the data.

Messages about deservingness have also been carried in portrayals of vulnerability, especially rooted in age and health. Children $363,364,365,366$ and elderly people are treated as deserving, ${ }^{367,368}$ as are the disabled, ${ }^{369}$ with some caveats. ${ }^{370,371}$ Families are viewed favorably, ${ }^{372}$ but single-parent households less so. ${ }^{373,374,375}$

Table 2 summarizes the groups and behaviors used in past constructions of deservingness or lack thereof as suggested by the aforesaid literature, roughly identifying how groups, or groups qua behaviors, have been used as foils against each other in politics according to that literature. It is similar to Schneider and Ingram's table of the positively and negatively constructed and includes groups (e.g. "The Rich," "dependents," Wall Street/"big" business) that they define, ${ }^{376}$ but unlike their table ignores power. It is also similar to Kim's table of traits and behaviors used as, essentially, signals of (un)deservingness, and attributed to people and groups in politics and media in the past. ${ }^{377}$

Table 2 has caveats. First, constructions of deservingness change over time. ${ }^{378,379}$ Second, there are historical exceptions to several groups' placement, including 


\section{Press depictions of ACA beneficiaries}

Table 2. A summary of the literature: Past divisions of deserving and undeserving.

\begin{tabular}{ll}
\hline \hline \multicolumn{1}{c}{ Frequent historical constructions of groups and behaviors } \\
\hline Deserving/favorable & Undeserving/unfavorable \\
\hline Business sector & "Big" business \\
Science sector & \\
Middle class & \\
Veterans/military & \\
Taxpayers & \\
Workers & \\
Education seekers & \\
Market participants/customers & \\
Physically disabled & Physically able adult non-workers \\
The elderly & \\
The poor/working poor & Welfare recipients \\
The dependent/needy & \\
Families & Single-parent households \\
Women (especially as mothers) & \\
Children & \\
Citizens & Non-citizens, immigrants \\
Insiders & Outsiders \\
White Americans & African Americans \\
& Asian Americans \\
\hline
\end{tabular}

immigrants, ${ }^{380}$ African Americans and Whites, ${ }^{381,382}$ Asian Americans, ${ }^{383}$ veterans, ${ }^{384}$ and seniors. ${ }^{385}$ Third, race/ethnicity references can overlap with insider/ outsider references, ${ }^{386,387}$ and are also "enmeshed"388 with ideas about work. ${ }^{389,390,391}$ And as noted, women's and mothers' perceived deservingness may vary by race, income, and marital status. Fourth, "[t]he ACA is disrupting long-standing patterns of American politics" 392 and so could alter the table.

\section{Data}

This paper aligns with past research on portrayals in studying news, ${ }^{393}$ newspapers, ${ }^{394}$ and newspaper text. 395,396 Druckman finds that "television news and newspapers... do not drastically differ in terms of content" and that "newspapers, and not television news, play a significant. . . role in informing the electorate."397 Others concur. ${ }^{398}$ Schneider and Ingram identify text as a source of portrayal data, ${ }^{399}$ and Oberlander also indicates that the "vocabulary" used in describing a policy's beneficiaries is a key influence on how they are politically understood. ${ }^{400}$

Newspaper articles discussing those eligible for Medicaid and/or subsidies under the ACA were collected through LexisNexis Academic, retroactively on February 3,2014. Articles identified as relevant to a state include those in newspapers based in that state, and those that mention that state printed in out-of-state papers, according to LexisNexis. The articles should thus reflect not only what residents may have read from state-based outlets, but what they (or elites or journalists) may have read about the state in other outlets. Complete search procedures are available on request. The search returned 8019 articles. The average number per state is 160.4 ( $\mathrm{SD}=155)$. California had the most (897), Delaware and Nebraska the fewest (18 each).

As noted, the articles run August 1, 2013 through January 31, 2014, starting two months before the first ACA open-enrollment period officially began and running through its first four months. This timing alone makes the period studied significant. At this time, many Americans first interacted with a major ACA policy output-insurance exchanges. Important pieces of the ACA that give it cross-class reach also took effect in this period. In these months, the ACA touched people with incomes well above the federal poverty line, with the initiation of subsidies on January $1,2014,{ }^{401}$ and touched those just above and far below the poverty line with the Medicaid expansion also intended for January 2014. ${ }^{402}$ This conveyance of "resources" likely helped the ACA begin to be "woven into the fabric of people's lives" in a way that it was not in its initial years. ${ }^{403}$ Also in these months, the ACA became squarely applicable to working-age Americans, beyond the young and elderly as in earlier years. ${ }^{404}$

The months studied are also prime for research on beneficiary portrayals because in these months, news stories about people signing up for insurance under the ACA were salient insofar as HealthCare.gov was salient. New York Times articles from the last quarter of 2013not drawn from the articles coded to build the text data for this article, any overlap being by chance-remarked on the "political crisis caused by... [the website's] disastrous debut," 405 noting that President Obama "had to stand in the Rose Garden to apologize for a broken Web site." 406 The website's problems prompted several, visible, executive branch actions from October to December 2013. ${ }^{407,408,409}$ The timeframe studied here coincides with and extends just beyond these events. This salience means that the portrayals studied here are ones many citizens likely encountered and possibly "received." $" 110$ 


\section{Chattopadhyay}

\section{Methods}

The Appendix provides a full description of the methods used to analyze the articles. In brief, the analysis included three phases. First, the author and graduate assistants manually coded select sentences in each state's article batch for descriptions of each of the four groups: the newly Medicaid-eligible, the subsidyeligible, insurance-gainers, and insurance-losers. For the first and third groups, coding excluded descriptions of people eligible for Medicaid prior to the ACA, joining it by what is known as the "woodwork effect." 411 For all groups, references to national-level information were coded, but final coded material should otherwise describe only residents of the state at hand, not of other states. Consequently, when it appears in the data, a term like "Californians" should come from a California article and thus signal an "insider" portrayal in the sense discussed in part III. Second, I harvested the words thus coded for each of the four groups, placing them in four documents ("bags of words" 412,413 ) for each state. I then assembled four "corpus[es]," 414 one consisting of the 50 documents (one per state) describing the newly Medicaid-eligible, a second the 50 describing the subsidy-eligible, a third the 50 describing insurance-gainers, and a fourth the 50 describing insurance-losers. I ran each corpus through basic automated textual processing in $\mathbf{R}$, making the unconventional choice not to reduce words to their roots and not to remove terms like "the," numbers, and punctuation ${ }^{415,416}$ in the interest of preserving information relevant to portrayals. I then generated four "document-term matri[ces]" ("DTMs"), ${ }^{417,418}$ one consisting of the terms describing the newly Medicaideligible, one the terms describing the subsidy-eligible, one the terms describing insurance-gainers, and one the terms describing insurance-losers. A DTM reports each unique term in a corpus and its frequency by document. ${ }^{419}$ Third, I manually assigned each term a "tag." Tags mainly stem from the literature reviewed in part III. For instance, "his" and male names such as "jonathan" were tagged Male. The term "our" was tagged Strong Insider given Winter's discussion of "our elderly." 420 A "dictionary" 21 lists the terms receiving each tag. Dictionary 1 (see online Appendix 1) contains 40 tags, which appear in the left-most column of Table 3. I created five alternative dictionaries (described in online Appendix 2) since terms can be differently tagged based on analyst interest. Results reported in detail are those from using Dictionary 1. Part VI mentions two other dictionaries ( 3 and 5), described in the Appendix.
To check if results would systematically differ using a database other than LexisNexis, an assistant gathered articles for August 1, 2013 through January 31, 2014 from NewsBank for ten states. Articles were analyzed, as above, for portrayals of the subsidy- and newly Medicaid-eligible. As part VI reports, results differ little from those the LexisNexis articles yield.

\section{Results}

Before answering the three questions set forth in the introduction and part III and assessing their implications, I report factual results for each DTM. Results are reported for the 50 states aggregated together. Since some articles appeared in the article batches of more than one state, the aggregate results up-weight portrayals that were more widespread. Although part IV makes clear that data were gathered at the state level, I do not assess cross-state portrayal variation. The ten-state NewsBank check is adequate only to tell us whether articles obtained through LexisNexis versus NewsBank would generate different results at the aggregate level. The NewsBank results suggest the answer is no; but, it is still possible that articles found through LexisNexis versus NewsBank carry systematically different portrayals at the state level. Whether this is the case requires study beyond this paper. By reporting results for the aggregate level, I report findings that the NewsBank check suggests would replicate reasonably well if articles were gathered through a database other than LexisNexis.

\section{The newly Medicaid-eligible}

The DTM for the newly Medicaid-eligible contains 1954 unique terms. Note that because punctuation was not removed before creating DTMs, terms that are the same but for punctuation variants count as unique; for example "younger" and "younger," are two unique terms. The DTM contains 15,406 terms total (the sum of the number of times that each unique term appears). Using Dictionary 1, I tagged 4917 of these 15,406 terms and left 10,489 (68 percent) that were generic or ambiguous untagged. (A high proportion of terms is untagged across all dictionaries, and for all DTMs, since I did not drop numbers and words like "the" before generating the DTMs. The terms Dictionary 1 left untagged appear in online Appendix 1). The first column of Table 3 lists the proportion of terms falling under each tag for the newly Medicaid-eligible. Of the 4917 terms tagged, 941 (19 percent) were tagged Workers. 


\section{Press depictions of ACA beneficiaries}

Table 3. Proportion of tagged terms receiving each tag, using Dictionary 1.

\begin{tabular}{|c|c|c|c|c|}
\hline Tag & New Medicaid & Subsidies & Losing ins. & Gaining ins \\
\hline Adults & 0.074 & 0.014 & 0.018 & 0.032 \\
\hline Bad health & 0.032 & 0.010 & 0.026 & 0.026 \\
\hline Business sector & 0.004 & 0.060 & 0.029 & 0.006 \\
\hline Children & 0.017 & 0.005 & 0.007 & 0.010 \\
\hline Criminals & 0.006 & 0.001 & no terms & no terms \\
\hline Cross class & 0.001 & 0.024 & 0.002 & 0.003 \\
\hline Customer/client & 0.016 & 0.087 & 0.077 & 0.018 \\
\hline Deserving (explicit) & 0.000 & no terms & no terms & no terms \\
\hline Education & 0.005 & 0.004 & 0.004 & 0.004 \\
\hline Families & 0.055 & 0.109 & 0.035 & 0.013 \\
\hline Female & 0.021 & 0.047 & 0.059 & 0.029 \\
\hline General low income & 0.004 & 0.001 & no terms & 0.000 \\
\hline Geography & 0.046 & 0.046 & 0.070 & 0.035 \\
\hline Good health/able-bodied & 0.002 & 0.004 & 0.002 & 0.003 \\
\hline Health care sector & 0.014 & 0.002 & 0.007 & 0.003 \\
\hline Immigrants & 0.001 & 0.001 & no terms & 0.001 \\
\hline Male & 0.009 & 0.021 & 0.037 & 0.015 \\
\hline Near elderly & 0.000 & 0.002 & 0.002 & 0.001 \\
\hline Non-Whites & 0.008 & 0.005 & no terms & 0.016 \\
\hline Outsiders (explicit) & no terms & 0.000 & no terms & 0.000 \\
\hline Personal & 0.004 & 0.019 & 0.037 & 0.005 \\
\hline Political elites & 0.001 & 0.012 & 0.011 & 0.000 \\
\hline Poor/very poor & 0.175 & 0.096 & 0.013 & 0.019 \\
\hline Public health ins. recipients & 0.012 & 0.003 & 0.024 & 0.003 \\
\hline Rural & 0.001 & 0.002 & no terms & no terms \\
\hline Same sex couples & no terms & 0.001 & no terms & 0.001 \\
\hline Seniors & 0.004 & 0.003 & 0.007 & 0.001 \\
\hline Strong insiders & 0.147 & 0.079 & 0.294 & 0.164 \\
\hline Substance abusers & 0.005 & 0.000 & no terms & 0.000 \\
\hline Surnames & 0.008 & 0.019 & 0.042 & 0.021 \\
\hline Undeserving (explicit) & 0.000 & 0.000 & no terms & 0.000 \\
\hline Unemployed & 0.000 & 0.000 & no terms & 0.001 \\
\hline Uninsured/underinsured & 0.068 & 0.031 & 0.026 & 0.439 \\
\hline Unmarried/divorced & 0.001 & 0.000 & 0.002 & 0.000 \\
\hline Veterans & 0.004 & 0.000 & no terms & 0.001 \\
\hline Vulnerable (explicit) & 0.002 & no terms & no terms & 0.000 \\
\hline Weak insiders & 0.055 & 0.028 & 0.033 & 0.063 \\
\hline Whites & 0.001 & 0.001 & no terms & 0.002 \\
\hline Workers & 0.191 & 0.242 & 0.136 & 0.051 \\
\hline Young adults & 0.004 & 0.019 & no terms & 0.011 \\
\hline Total terms in DTM & 15,406 & 19,706 & 1,354 & 10,455 \\
\hline Total terms left untagged & 10,489 & 14,144 & 898 & 5,015 \\
\hline
\end{tabular}

Note: Where no terms in the DTM received the tag, "no terms" appears; 0.000 is non-zero.

(This figure derives from 66 unique terms tagged Workers, many of which appear in the DTM multiple times, together yielding 941 instances of the Worker tag.) In addition, 18 percent were tagged Poor/Very Poor, and 15 percent were tagged Strong Insiders. The remaining tags appeared less often, as seen in Table 3. For simplicity, I round percentages in reporting results within this article.

The results are similar when using the other dictionaries. Using Dictionary 3, the share tagged Workers falls to 16 percent and that tagged General Low Income rises to 11 percent, but Workers is still the most frequent tag. Only with Dictionary 5 is Workers not the most frequent tag; there, Poor/Very Poor is the most frequent (18 percent) followed by Strong Insiders (15 percent), followed by Workers (13 percent). Across all dictionaries, some ordering of Workers, Poor/Very Poor, and Strong Insiders are the three most frequent tags.

That said, the Poor/Very Poor tag's frequency here, and in other results, may owe in part to two factors that analyzing the terms with different dictionaries cannot address. First, it may owe to the prevalence of simple, factual descriptions of the newly Medicaid-eligible as being at or below 133 or 138 percent of the federal poverty line. In Dictionary 1, 861 total terms (from 20 


\section{Chattopadhyay}

unique terms) were tagged Poor/Very Poor. The term "poverty" and its punctuation variants account for 483 of the 861 total terms, and the term "poverty-level" for one of these terms, equating to a non-trivial 56 percent. Yet, the remaining 377 total terms that received this tag come from the unique terms "homeless" "impoverished" "indigent" "neediest" "needy" "poor" "poorer" and "poorest" (or their punctuation variants), meaning at least 43 percent of this tag does not simply refer to the FPL. In particular, "poor" and its punctuation variants account for 287 of the 861 total Poor/Very Poor terms, and "poorest" an additional 60. A second possibility that using multiple dictionaries cannot address is that the Poor/Very Poor tag's frequency stems in part from coders being unable to separate the newly Medicaideligible from the traditionally Medicaid-eligible and accidentally coding the latter in the text. If this is the case however, the mistake is likely indicative of how the newly Medicaid-eligible are perceived. (Note that the assistants involved in this coding had completed multiple semesters of masters-level public administration coursework and should be no less informed on the distinction than other newspaper readers.)

\section{The subsidy-eligible}

The DTM for the subsidy-eligible contains 2092 unique terms and 19,706 terms total. The second column of Table 3 lists the proportion of terms in each tag using Dictionary 1. I here tagged 5562 terms and left 14,144 (72 percent) untagged. The most frequently used tag is Workers (24 percent), followed distantly by Families (11 percent), Poor/Very Poor (10 percent), Customers/Clients (9 percent), and Strong Insiders (8 percent). Here, the term "poverty" and its variants drive the Poor/Very poor tag (over 91 percent of terms). Instances of the word "poverty" that occur due to explicit mentions of people with incomes falling between 100 and 400 percent of the federal poverty level would portray the subsidy eligible as cross-class. But, this would appear to be the case for at most 60 percent of the instances of "poverty" since the term "400" and its variants appear only 297 times in the DTM, while poverty and its variants, plus three instances of "poverty-level" together appear 492 times. Workers remains the most frequent tag when using the other dictionaries, and for five dictionaries, some ordering of Workers, Families, and Poor/Very Poor makes up the top three tags. The exception is that in Dictionary 3, the tag Cross Class is the second-most frequent (just under 15 percent), thus also supporting the possibility that there are references to the cross-class nature of this group; with this dictionary, Workers is still the most frequent tag, and Families the third most frequent.

\section{NewsBank check for the newly Medicaid-eligible} and subsidy-eligible

As noted, analyses of portrayals of the subsidy- and the newly Medicaid-eligible were also performed using articles located through NewsBank for ten states. I coded the DTMs obtained from this work using Dictionary 1 , albeit that a small number of terms had to be assigned a tag here for the first time by virtue of not appearing in the LexisNexis articles. (Dictionary 1 in online Appendix 1 does not include these new terms; they are available by request.)

In the resulting Medicaid DTM, there are 747 unique terms and 4641 terms total, 66.5 percent of which were left untagged. For the 1556 terms tagged, top tags were Strong Insiders (20 percent), followed by Workers (19 percent) and Poor/Very Poor (18 percent). The top three tags are thus the same as in the Dictionary 1 LexisNexis results, although their ordering differs.

In the subsidy DTM from this work, there are 733 unique terms and 5287 terms total, 71 percent of which were left untagged. For the 1512 terms tagged, the top tags are Workers (25 percent), Families (13 percent), and Poor/Very Poor (12 percent). These results too are very similar to the Dictionary 1 LexisNexis results. Full NewsBank results are available on request.

\section{Insurance-losers}

The DTM for insurance-losers consists of 366 unique terms and 1354 terms total, 66 percent of which were untagged. The third column of Table 3 lists the proportion of terms in each tag using Dictionary 1. For the 456 terms tagged, Strong Insiders is most frequent (29 percent), followed by Workers (14 percent) and Customers/Clients ( 8 percent). Strong Insiders is the most frequent tag using any dictionary (29 to 30 percent of tagged terms in each case).

\section{Insurance-gainers}

The DTM for insurance-gainers consists of 1447 unique terms and 10,455 terms total, 48 percent of which were left untagged. The fourth column of Table 3 lists the share of terms in each tag using Dictionary 1 . For the 5440 terms tagged, the tag Uninsured/Underinsured dominates by a wide margin (44 percent), followed distantly by Strong Insiders (16 percent), Weak Insiders (6 percent), and Workers 


\section{Press depictions of ACA beneficiaries}

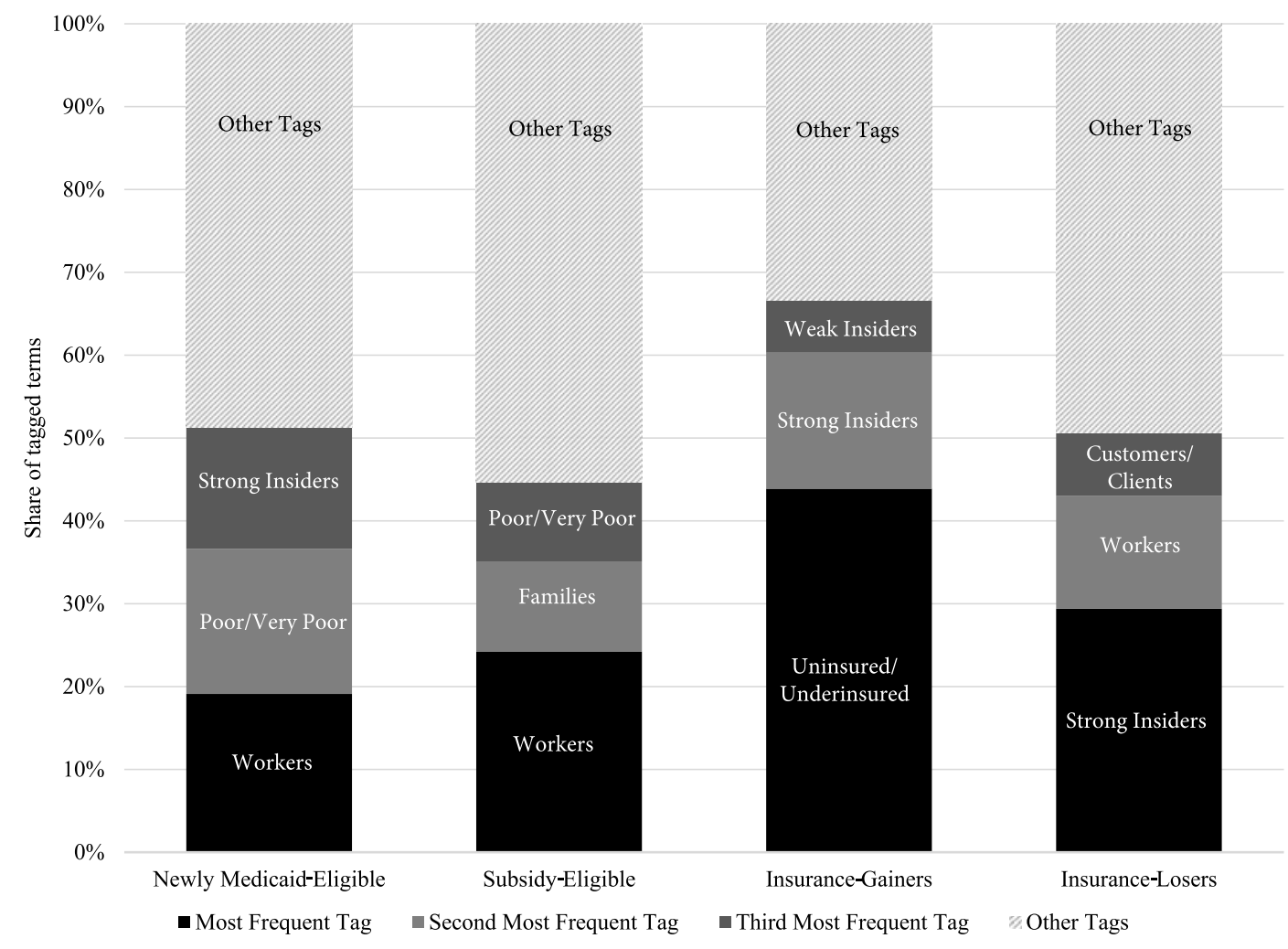

Figure 1. Top three tags as shares of tagged terms, by group.

Table 4. Top three tags for each ACA group.

\begin{tabular}{llll}
\hline \hline Group & Most frequent tag & Second most frequent tag & Third most frequent tag \\
\hline Newly Medicaid-eligible & Workers & Poor/very poor & Strong insiders \\
Subsidy-eligible & Workers & Families & Poor/very poor \\
Insurance-gainers & Uninsured/underinsured & Strong insiders & Weak insiders \\
Insurance-losers & Strong insiders & Workers & Customers/clients \\
\hline
\end{tabular}

(5 percent). Uninsured/Underinsured is the most frequent tag using any dictionary (42 to 44 percent in each case). In Dictionary 1 , the term "uninsured" and its punctuation variants account for 98 percent of the 2387 terms with this tag.

\section{Discussion: answers to the three descriptive questions}

We can now answer the descriptive questions about portrayals outlined above, and then discuss their implications in part VIII. To aid the discussion, Table 4 recaps the top three tags (using Dictionary 1 ) in por- trayals of the newly Medicaid-eligible, subsidy-eligible, insurance-gainers, and insurance-losers. Figure 1 illustrates their proportions as a share of tagged terms.

1. Are ACA beneficiaries portrayed as economically heterogeneous?

Terms signaling income heterogeneity among ACA beneficiaries were tagged Cross Class. (See online Appendix 1 for details for Dictionary 1.) This tag is absent from Table 4. Under any dictionary, this tag accounts for less than 2 percent of tagged terms describing the newly Medicaid-eligible, and less than 1 percent of tagged terms describing insurance-gainers (and insurance-losers). It accounts for 15 percent of terms in 


\section{Chattopadhyay}

the subsidy DTM when using Dictionary 3 but virtually the same share as in Dictionary 1 (2.4 percent) using the other dictionaries.

By definition, the newly Medicaid-eligible are those 138 percent FPL or below, so it is logical that Cross Class terms are infrequent in portrayals of this group. But the infrequence of cross-class terms in portrayals of the subsidy-eligible-at least absent strong assumptions about numbers-may signal an under-representation of the de jure cross-class nature (100-400 percent FPL) of this group in media portrayals. The infrequence of Cross Class terms in portrayals of insurance-gainers may also understate the prevalence of middle income earners in this group. Government data on the incomes of those receiving ACA benefits do not yet appear to exist, but estimates suggest that, among previously uninsured adults gaining insurance after the ACA, over 40 percent have family incomes ranging 139 percent to 399 percent FPL, and over 10 percent have family incomes at 400 percent FPL or more. ${ }^{422}$ Such figures reinforce arguments by Skocpol and Jacobs and others that ACA beneficiaries are economically diverse. ${ }^{423}$ Yet especially for insurance-gainers, portrayals do not appear to underscore this economic heterogeneity, and so likely failed to help address indications that "many low to middle income Americans remained unaware of the law's key features and were skeptical that it will actually help them" as of 2013. ${ }^{424}$ Thus, portrayals may fail to help bestow on the ACA the political strength many find around cross-class policies.

An important caveat is the possibility that cross-class portrayals abound but are missed by the methods here. This would happen if cross-class markers largely surface in numbers rather than words, as the dictionaries (albeit \#3) leave many numbers untagged since they are difficult to interpret without context. (And even Dictionary 3 leaves numbers lacking “\$” signs largely untagged.) Fully detecting cross-class portrayals may require different methods.

2. Do portrayals of beneficiaries highlight groups to which the ACA gives new political relevance?

As noted in part III, the ACA gives new political relevance to being a young adult under age 26 . The U.S. Department of Health and Human Services (HHS) reports that 28 percent of those who selected an insurance plan on ACA exchanges in the first open enrollment period were aged 18 to $34 ;^{425}$ (age 18 to 26 data appear unavailable). Young adults were thus indeed a non-trivial share of exchange-based enrollees. Yet, references to young adults make up less than 2 percent of tagged terms in all four DTMs (albeit 2.2 percent of the subsidy DTM and 2.6 percent of the insurance-gainer DTM using Dictionary 3). Their infrequent mention suggests that ACA beneficiary portrayals from these months are unlikely to advance a perception-among young adults themselves, the mass public, or political elites-that young adults have what Campbell would call an "identity as a program clientele." 426

The methods could miss some age references strictly carried in numbers. It could also be that portrayals of young adults were higher in 2010, when eligibility to remain on parental insurance took effect. ${ }^{427}$ But even if this is so, the fact that attention to young adults apparently did not persist into 2013-2014 may be a finding in support of Jacobs' warning that the ACA "may fall short of the mobilizing impacts documented by scholars of policy feedback." $" 28$

3. What themes that have served as messages about beneficiary "deservingness" in past social policy are most frequent in ACA beneficiary portrayals?

Table 4 suggests that messages about workforce participation, economic self-sufficiency, and insider status, are the key themes or routes through which portrayals may be signaling beneficiary (un)deservingness in the case of the ACA. As detailed above, the Workers tag is the most frequent tag in descriptions of the newly Medicaid-eligible and the subsidy-eligible, and the second most frequent in descriptions of ACA insurance-losers. The Poor/Very Poor tag is one of the three most frequent in portrayals of both the newly Medicaid-eligible and the subsidy-eligible, and the Customers/Clients tag is one of the three most frequent in portrayals of ACA insurance-losers. The Strong Insiders tag is among the three most frequent in portrayals of the newly Medicaid-eligible, ACA insurance-gainers, and ACA insurance-losers.

Other signals about deservingness discussed in part III-such as messages about health, age, gender, and race/ethnicity-appear relatively infrequent in portrayals of ACA beneficiaries, as seen in Table 3. Regarding health, the Bad Health tag applies to less than 4 percent of terms in each DTM, and the Good Health/Able Bodied tag to less than 1 percent of terms in each DTM.

Age-related tags are absent from Table 4. Beyond Young Adults, the Near Elderly tag makes up less than 1 percent of tagged terms in each DTM when using Dictionary 1, even though this group may particularly stand to benefit from ACA regulations. ${ }^{429,430}$ Adults is the most frequent age tag in portrayals of the newly 


\section{Press depictions of ACA beneficiaries}

Medicaid-eligible (7.4 percent of tagged terms) and of insurance-gainers (3.2 percent) using that dictionary. And for the subsidy-eligible, Adults and Young Adults appear rarely and with near equal frequency (respectively 1.4 and 1.9 percent of tagged terms).

References to gender are also infrequent. Within the references that exist, across all DTMs, portrayals are somewhat more focused on women than men (see Table 3 for details). Women's slightly greater frequency in portrayals appears commensurate with women's actual prevalence as ACA beneficiaries. At least of those who selected an insurance plan through ACA marketplaces during the first open enrollment period, an estimated 54 percent were female. ${ }^{431}$

Explicit references to race also appear infrequent. As seen in Table 3, across all four DTMs, both White and non-White references are less than 2 percent of tagged terms (and are absent in descriptions of insurancelosers). While potentially related to salience, ${ }^{432,433}$ it is not possible to assess whether portrayals of race/ ethnicity are proportionate. Explicit mentions of race/ ethnicity appear most in descriptions of insurancegainers, who are portrayed as more often non-White (1.6 percent of tagged terms) than White (0.2 percent of tagged terms). In California, which as noted accounts for many of the articles and thus plays a large role in the data, a minority (35 percent) of marketplace enrollees were non-Hispanic White. ${ }^{434}$ Nationally, HHS reports race/ethnicity information for people who selected insurance on federally-facilitated marketplaces as of May 1, 2014. ${ }^{435}$ In those data, of the 69 percent who reported a race, 63 percent identified as White. ${ }^{436}$

There are also methodological caveats to assessing the frequency of references to race/ethnicity. The methods may undercount explicit references since none of the dictionaries break out terms tagged as Surnames (see the Appendix) by national origin. ${ }^{437,438}$ Second, as noted, the White and non-White tags will miss implicit race references- "words that have racial associations but are not racial nouns or adjectives." 439 Third, as part III notes, scholars find messages about race/ethnicity interlaced with messages about insiders/outsiders and messages about work. As Table 4 underscores, the Workers tag and Strong Insiders tag are among the most frequent in portrayals.

\section{Implications for durability}

Are the patterns these questions have uncovered favorable to the ACA's durability, as defined at the outset of the paper? This section offers two broad answers for consideration. On the one hand, portrayals appear conducive to durability in that they depict beneficiaries in terms associated with deservingness in past U.S. social policy. On the other hand, there are three reasons for caution. First, portrayals also cast insurancelosers as deserving. Second, it is unclear if the portrayals found will aid, or allow "drift" 440 away from, the ACA's goals of cutting insurance disparities. Research is needed on the implications of the (non)-role of race/ethnicity, along with age and health, in portrayals, and the prominent role of the insider theme. Third, the frequent portrayal of beneficiaries as Workers, coupled with the inattention to young adults and to beneficiary economic heterogeneity, may do little to foster beneficiary political engagement.

\section{How portrayals may bolster durability: beneficiaries as deserving}

The likely query following from the third question taken up in part VII is whether portrayals depict ACA beneficiaries as deserving. As part III explained, such a portrayal is associated with favorability toward the policy in question among beneficiaries, the mass public, and elites. We can give a preliminary answer by examining Table 4 in light of Table 2 . Three points suggest that ACA beneficiaries (the newly Medicaid-eligible, the subsidy-eligible, and insurance-gainers) are portrayed as deserving.

First, as noted, Workers is the tag that most often appears in portrayals of the subsidy- and newly Medicaid-eligible. In the subsidy DTM, it is the most frequent tag by over 13 points. As part III notes, workforce participation is a hallmark of deservingness in U.S. social policy.

Second, as Table 4 underscores, the second most frequent tag in descriptions of the subsidy-eligible is Families. As noted, families are often considered deserving, and the Families and Workers portrayals may interact to support durability, as "supplements for working families with low incomes" have seen expansion even when politics otherwise favored retrenchment. ${ }^{441}$

Third, as Table 4 recaps, Strong Insiders is the third most frequently used tag in descriptions of the newly Medicaid-eligible, and the Strong and Weak Insiders tags are the second and third most frequent tags for insurance-gainers. As noted above, claims that beneficiaries are insiders have often been associated with claims that beneficiaries are deserving. 


\section{Chattopadhyay}

It is useful to present further information about which terms "drive" the Strong Insiders tag. For instance, in all dictionaries, the term "state's" (possessive) is tagged Strong Insider. Readers may wonder whether the tag's frequency owes to uses of "state's" that may reference say, a "state's" government or institutions, rather than people. This does not appear to be the case. Using Dictionary 1 , in the subsidy DTM, the term accounts for only three of the 438 instances of the Strong Insiders tag; the most frequent terms were "americans" (201 instances), followed by "taxpayer" (22 instances), "californians" (18 instances), "citizens" (13 instances), and "virginians" (12 instances). In the Medicaid DTM, it accounts for 31 of the 721 instances of the Strong Insider tag (4 percent); ahead of it were "americans" (130 instances), "virginians" (44 instances), and "ohioans" (33 instances). Closely following it were "utahans" (28 instances), "citizens" (26 instances), "pennsylvanians" (24 instances), "americans." (21 instances), "texans" (20 instances), and "mainers" (19 instances). In the insurance-gainers DTM, it accounts for 24 of 890 instances of the Strong Insiders tag (under 3 percent); frequent terms are "americans" (443 instances), "floridians" (35 instances), "americans." (26 instances), and "nation's" (24 instances). The term does not appear in the insurance-losers DTM. Thus, newspapers appear to describe ACA beneficiaries with words of the sort that past scholars have identified as signaling "insider" status, as discussed in part III.

The two other tags most often seen in portrayals as recapped in Table 4-Poor/Very Poor and Uninsured/ Underinsured-also likely cast ACA beneficiaries as deserving when closely assessed. As noted, past research finds the poor-at least the working poor-on the deserving side of Table 2. To further assess the Poor/Very Poor tag in the context of the ACA, recall that a portrayal's impact depends partly on how it aligns with existing views of a group or characteristic. ${ }^{442}$ To that end, it is interesting to note that traditional Medicaid recipients have historically been seen with sympathy. ${ }^{443}$ And, an April 2005 survey that asked national adults if they thought "a main reason why people have health insurance through the Medicaid program" is that "they are poor and can't afford to purchase health insurance on their own," found 87 percent saying "yes." 444 Together, these considerations suggest that the public thinks of traditional Medicaid recipients as poor but deserving. Thus, portrayals of the newly Medicaid-eligible as Poor/Very Poor are also likely consistent with a view of this group as deserving.
Uninsured/Underinsured-the dominant tag in portrayals of insurance-gainers-also likely connotes deservingness. As noted, this tag comes almost entirely from mentions of the "uninsured." Surveys shed light on views of the uninsured. In five closed-ended questions between 1993 and 2001 that allowed multiple responses and asked Americans to describe the uninsured, the "Poor" and "Poor people" were chosen most often (by 41 to 48 percent of respondents), followed by "Unemployed" or "Unemployed people" (35 to 37 percent), while only 10 to 16 percent chose "Working" or "Working families" in all five surveys, and only 6 to 8 percent selected "People like yourself" or "Like yourself" in the four giving this option. ${ }^{445,446,447,448,449}$ Similar questions permitting open-ended responses also find an emphasis on "Unemployed people" and "Poor people" or "Poor people/low income people." 450,451,452 Again, beliefs that the uninsured are poor or low-income suggest they are seen as deserving. It is more difficult to predict the upshot of beliefs that the uninsured are unemployed, especially since the Workers tag characterizes only 5 percent of terms describing insurance-gainers. As part III notes, work is a cornerstone of deservingness in social policy; but, the public does not always take unemployment as signaling an unwillingness to work, particularly during a recession. ${ }^{453}$ Further, one of those surveys finds the uninsured associated with the unemployed and "Working families/Employed" at similar rates, ${ }^{454}$ and Schneider and Ingram suggest the unemployed are often seen as deserving. ${ }^{455}$ The dominant depiction of insurance-gainers as uninsured thus appears unlikely to work against a portrayal of this group as deserving, particularly in light of their simultaneous portrayal as Insiders.

There is arguably an example of what Ingram and Schneider call "degenerative politics" 456 in discussions of beneficiaries as "smokers," and "drinkers."457,458 But, these discussions appear to dissipate and are a very small data share (Substance Abusers in Table 3).

Thus, portrayals of ACA beneficiaries (the subsidyeligible, newly Medicaid-eligible, and insurance-gainers) appear to emphasize themes tied to deservingness in past U.S. social policy. A depiction of beneficiaries as deserving may aid in benefit take-up, foster favorability to the ACA in the mass public, ${ }^{459,460}$ nurture beneficiaries' "external" political efficacy ${ }^{461}$ and political participation, ${ }^{462}$ and thereby help to insulate the ACA from "“programmatic retrenchment." 463 


\section{Press depictions of ACA beneficiaries}

\section{Three reasons for caution}

Yet, as outlined above, three considerations give reason for caution in concluding that portrayals in all respects advance the ACA's policy durability, as defined at the article's outset.

\section{Insurance-losers as deserving}

A caveat to the finding that ACA beneficiaries are portrayed as deserving is that ACA insurance-losers are also strongly portrayed as deserving, and in ways that could be sharpened into bright contrasts with insurancegainers. As seen in Table 3 and recapped in Table 4 and Figure 1, the dominant tag in portrayals of insurancelosers is Strong Insiders. And, it is seen far more often for this group (29 percent of tagged terms) than it is for insurance-gainers (16 percent of tagged terms). The second most frequent tag in portrayals of insurance-losers is, as noted, Workers (14 percent of tagged terms), compared to this tag applying to only 5 percent of tagged terms describing insurance-gainers. The third most frequent tag in portrayals of insurance-losers is, as noted, Customers/Clients, another group that, as part III discusses, has been considered deserving in the past in American politics. These portrayals all serve to cast insurance-losers as highly deserving according to the literature, and could conceivably serve to turn insurancegainers' dominant portrayal as the Uninsured into a signal of undeservingness in the future-particularly if the association the public makes between the uninsured and the unemployed were to tighten, and perceptions of the unemployed to turn negative. It will be important to trace whether the categories of insurance-gainers versus insurance-losers persist, and to continue to track how each is portrayed.

\section{Portrayals and the durable pursuit of disparity reduction}

Two aspects of the results require further studyoutside this paper-to assess whether the patterns found stand to bolster or weaken the durability of the ACA's efforts to cut insurance disparities: (1) the implications of the infrequent attention to race/ethnicity, as well as to age and health; and (2) the implications of the salient attention to insider status.

Much literature suggests that race/ethnicity's role in portrayals could relate to the ACA's ability to reduce race/ethnic insurance disparities. ${ }^{464,465,466,467,468}$ If the apparent inattention to race/ethnicity found in part VII means an absence of the sorts of negative portrayals of minorities that Gilens and Neubeck and
Cazenave describe, this is favorable for racial equality in politics, ${ }^{469,470}$ and potentially for ACA durability insofar as some past policies standing to cut racial disparities that have been linked to racial stereotypes have faced direct retrenchment ${ }^{471}$ or attenuated efficacy. ${ }^{472,473} \mathrm{Si}^{-}$ multaneously, Schram argues that when race is ignored, little attention may be paid to whether a policy that aims to reduce disparities is actually doing so, and that inequalities, especially between African Americans and Whites, could thereby be "reinforce[d]." " work echoes this concern, ${ }^{475,476}$ including, broadly, research on media portrayals of disease. ${ }^{477}$ Discussing welfare, Schram advocates "tak[ing] race into account," and directly attending to the "racial dimensions of our social and economic structure" when aiming to cut disparities. ${ }^{478}$ A range of scholarship makes a similar argument. ${ }^{479,480,481,482,483}$ This call may be relevant to the ACA, with attention to how income and race condition access to employment-based health insurance being but one example. ${ }^{484,485,486,487,488}$

The political science literature is less developed around age and health, and as noted, race has a unique role in American politics. But by similar logic, the infrequent attention to age and health found in part VII has unclear implications for the ACA's work to cut insurance disparities between the near-elderly and those who are younger, and between those in poor versus good health.

The literature suggests a three-step mechanism by which the Strong Insider theme's salience could hinder the durability of the ACA's disparity cutting efforts by discouraging benefit take-up among eligible immigrants. First, portraying beneficiaries as insiders implicitly highlights outsiders. ${ }^{489,490}$ Second, undocumented immigrants are outsiders to ACA benefits. They cannot purchase insurance in exchanges, and eligible children must provide documentation to do so. ${ }^{491}$ The Strong Insider portrayal, as noted, also describes ACA beneficiaries using words such as "californians" and "citizens"- terms that have underscored undocumented immigrants' outsider status in the past. ${ }^{492}$ Third, factors highlighting undocumented persons' ineligibility for benefits can "chill" take-up by eligible immigrants and co-ethnics due to deportation fears, ${ }^{493}$ and there is some indication of elite concern about this possibility playing out in the ACA. ${ }^{494,495}$ In some cases, "any reminder of... immigration status may be sufficient to cue a 'chilling effect." 496 If so, the Strong Insider theme's preeminence could work against the ACA reducing 


\section{Chattopadhyay}

insurance disparities, especially between non-Hispanic Whites and Latinos. ${ }^{497,498}$

Thus, for multiple reasons, further research may be needed to assess whether the portrayal patterns found here stand to support or slacken the ACA's adherence to its disparity cutting aims. This question may especially merit study at the state level. ${ }^{499,500}$ Elites indeed already appear to be monitoring the ACA's fidelity to its disparity reducing goals. ${ }^{501}$

\section{Portrayals and beneficiary political engagement}

The portrayals found may also fail to politically mobilize ACA beneficiaries. Part VII already noted two ways in which this is so: portrayals do little to showcase the new political relevance of being under age 26 and so do little to foster positive feedbacks among young adults; and, portrayals do little to underscore beneficiaries' economic heterogeneity and so do little to help address Mettler's concern that many Americans "gained little understanding of what the policy might do for them." 502 Yet, one more aspect of the portrayals may impede positive feedbacks according to arguments by Mettler and others: the salience of the Worker theme.

While work is associated with deservingness, some scholars might argue that the Worker portrayal underscores beneficiaries' economic role more than their political capacity. Mettler worries that political engagement around social policy is unlikely when a policy and its politics "regard people primarily as... participants in markets" when "[f]undamental to democracy, by contrast, is the idea that people are... active participants in governance." ${ }^{203}$ Ono and Sloop make a similar argument, ${ }^{504}$ and Soss, Fording, and Schram's arguments about neoliberalism as a "policy rationality" 505 tend toward a similar conclusion. ${ }^{506}$ The Worker portrayal joins ACA features-like subsidies-that may already underscore citizens' market role. ${ }^{507}$ And, the portrayal may in itself be insufficient to suggest that ACA benefits are earned; not just beneficiaries' work history, but payroll taxes, help generate this view of Social Security and Medicare. ${ }^{508,509,510}$ If the ACA's beneficiaries-its "consumers" 511 -are politically dormant, then the ACA may, like Medicaid, ${ }^{512,513,514}$ derive political strength from the "producer" side of its constituency ${ }^{515}$ - the health care industry. $516,517,518$ But, "divisions between health-care producers and consumers...have facilitated retrenchment in Medicare," ${ }^{19}$ and "[d]ivide-and-conquer strategies"520 have similarly fostered cuts in antipoverty policies. ${ }^{521}$ Mettler in fact alludes to this risk within submerged policies. ${ }^{522}$ Campbell notes that "variation in program trajectories [can] aris[e] from the interaction of... design features with the political strategies of program foes." 523 Thus, if the Worker portrayal enables rather than counters beneficiary political dormancy, its preeminence could leave the ACA more vulnerable to retrenchment than it otherwise may be.

\section{Conclusions}

If the ACA achieves the goals noted in the Introduction, it may extend the American welfare state's "scope of risk protection," 524 and by "reduc[ing] vulnerability" even help address entrenched inequalities. ${ }^{525}$ This article therefore takes the premise that the ACA's durability merits scholarly interest, and-motivated by past research on social policy, welfare state retrenchment, and social constructions that suggests that a policy's durability relates to depictions of its beneficiaries-takes the premise that ACA beneficiary portrayals merit systematic study. This article first describes those portrayals by answering three questions that the literature connects to durability: (1) Are beneficiaries portrayed as economically heterogeneous? (2) Do portrayals highlight groups to which ACA gives new political meaning? (3) What themes that have served as messages of "deservingness" in the past riddle ACA portrayals? It finds the answer to question (1) to be "no," with the caveat that the methods may miss some cross-class portrayals. The answer to question (2) also appears to be "no," with the caveats that young adults may have received more attention in months prior to those studied, and that the methods may miss some references to age. In response to question (3), portrayals most often highlight themes of work, economic self-sufficiency, and insider status. Health status, age, gender, and race/ethnicity appear to receive little attention.

The article then assesses how the patterns uncovered in answering these descriptive questions may work for and against durability. While "[i]t is hazardous to make predictions about how policies will evolve, especially about those with as many moving parts as the ACA," 526 these findings-assessed through the lens of existing literature-suggest reasons for both confidence and caution about whether portrayals are likely to bolster the ACA's strength in resisting direct retrenchment and in diligently pursuing goals such as disparity reduction. To recap part VIII, a key result favoring durability is that beneficiaries are depicted in terms associated 


\section{Press depictions of ACA beneficiaries}

with deservingness in past U.S. social policy, in being portrayed as workers and insiders. But, there are three potential reasons for caution. First, ACA insurancelosers are also portrayed as deserving. Second, the durability of the ACA's disparity cutting efforts may merit watching, with an eye to the unclear impacts that the relative absence of age, health, and race/ethnicity in portrayals, and the possibly adverse impacts the Strong Insider theme's salience in portrayals, may have on this goal. Third, the Worker theme's salience may, despite its ties to deservingness, join limited attention to young adults and to beneficiaries' economic heterogeneity, as a portrayal pattern that does little to help the ACA politically mobilize its beneficiaries.

This article is the first to quantitatively describe and analyze media portrayals of ACA beneficiaries. Of studies located through JSTOR and other search strategies in May 2015 (details available by request), only a handful appear likely to speak to ACA beneficiary depictions, ${ }^{527,528,529,530,531}$ and inspection makes clear that the first three do not. Hussey and PearsonMerkowitz state that ACA "discourse... did not portray blacks as the likely beneficiaries of national health insurance or health care reform, while it did focus on illegal immigrants." 532 Their paper points to two New York Times articles exemplifying immigrant-focused discussions, but not to systematic studies of ACA beneficiary portrayals, and the paper itself examines a different question. ${ }^{533}$ Leimbigler's work shares the present article's interest in studying how social constructions relate to the ACA's political strength, ${ }^{534}$ discusses political engagement, ${ }^{535}$ and in studying "markets" and "rights" frames may trace language similar to that tagged Strong Insider, Cross Class, and Customer/Client here. ${ }^{536}$ But Leimbigler's work studies elite framing, and differs from this article in its goals, ${ }^{537}$ methods, ${ }^{538}$ and outputs. ${ }^{539}$ Barry and colleagues study media messages during ACA implementation but not beneficiary portrayals. ${ }^{540}$

Early beneficiary portrayals-such as those studied here-may have uniquely powerful implications, ${ }^{541,542}$ and data of the type gathered here may be a foundation for broaching large questions falling beyond this article, such as whether the ACA is understood as "public assistance" or "social insurance," a ubiquitous distinction. ${ }^{543,544,545}$ As noted, the data may be a basis for studying how the ACA may alter inequalities in political participation. ${ }^{546}$ The type of data built here may also be a start at answering Jacobs and Mettler's call for research on the "structural framing" around the ACA, ${ }^{547}$ meaning "institutionally-based communications of social welfare policies that... frame concrete programmatic returns to individuals." ${ }^{248}$

It is important to stress, however, that the research carried out here does not claim to describe framing effects around the ACA or its beneficiaries. It reports the frequency of tags devised to organize carefully coded but atomized terms; "framing effects depend more heavily on the qualities of frames than on their frequency of dissemination." 549 This article does not (and cannot) weight ACA beneficiary portrayals by the degree to which the public, beneficiaries, or policymakers find them convincing. These are empirical questions about which we do not yet have data.

Several other methodological limitations were stated above and are not repeated here. I rather highlight three points about external validity. First, as noted, results pertain to the 50 states in the aggregate; sub-national results may differ. Second, visual images-not studied here-may bear as much or more on beneficiary constructions as do numbers and words. ${ }^{550,551,552,553,554}$

Third, the degree to which the results generalize outside the months studied is an open question. One consideration is that the ACA's implementation timeline may make it logical for the media to generate different portrayal patterns at different times. Another is the partisan discord in the timeframe studied. In November 2013 for instance, the "Because of Obamacare... I Lost My Health Insurance" booklet met with a White House document entitled "'G.O.P. Obstruction/Sabotage-Affordable Care Act." ${ }^{555}$ Representative Frederick Upton (R-MI) charged President Obama with misleading Americans on being able to keep their insurance, and Representative Michael Doyle (D-PA) retorted “'[d]on't pretend you care about the American people's health care here.... You just want to repeal the Affordable Care Act." 556 Whether partisan discord impacted media portrayals is a question beyond this paper. So is the question of whether any such impact makes the portrayals found here unique to these months, or rather predictive of future portrayals.

Looking forward, tight public budgets may lead to a sharpening of divisions between those deemed "worthy and unworthy" 557 within a policy's beneficiaries. ${ }^{558,559}$ It will be important to continue to track ACA beneficiary portrayals in the coming years, using multiple methods, to update the answers to the questions broached here, and to continue to assess how the politics around this new policy are shaping its capacity 


\section{Chattopadhyay}

to insure the uninsured, mitigate health-based financial vulnerabilities, cut inter-group disparities, and improve health.

\section{Note}

This work was supported, in part, by funds provided by the University of North Carolina at Charlotte. For research assistance, I thank Marc Botero, Brittany Bumgarner, Kim Hill, Jenny Kaemmerlen Kabool, Charlie Lamprecht, Tracy Martin, Allison McMurry Cordell, Erika (Palmer) Ruanne, JoEllen Pope, and Ashlyn Shrewsbury. For information about LexisNexis indexing, I thank Amanda Binder. A course on "Text Mining and Text Analysis with $R$ " taught by Scott Moser in 2013 provided instructive guidance on performing automated text analysis in $\mathbf{R}$. Early versions of this paper were presented at the annual meetings of the American Political Science Association (August 2014), Midwest Political Science Association (April 2014), Northeastern Political Science Association (November 2013), and Southeastern Conference for Public Administration (September 2013). For helpful discussions and comments, I thank other panel participants at these conferences, Bill Brandon, Erik Bucy, Eileen Burgin, Sally Cohen, Nicole Krassas, Ted Marmor, Carl Snook, Robert Sprinkle, Deborah Stone, John Szmer, and Miya Woolfalk. I also thank two anonymous reviewers for helpful suggestions, including but not limited to the suggestion to examine portrayals of those gaining insurance versus those losing insurance under the ACA. Errors are my own. For references citing iPOLL as the distributor, the following acknowledgement applies, as stated by the Roper Center website: "The survey results reported here were obtained from searches of the iPOLL Databank and other resources provided by the Roper Center for Public Opinion Research, University of Connecticut." The author's access to Roper iPOLL was obtained through UNC Charlotte. Online Appendices 1, 2 and 3 are available as supplementary material on Cambridge Journals Online. Data are available from the author.

\section{References}

1. Lawrence R. Jacobs, "America's critical juncture: The Affordable Care Act and its reverberations," Journal of Health Politics, Policy and Law, 2011, 36(3): 625-631, at p. 626.

2. Lawrence R. Jacobs, "What health reform teaches us about American politics," PS: Political Science \& Politics, 2010, 43(4): 619-623, at p. 619.
3. President Barack Obama, "Remarks by the President on the Affordable Care Act," April 1, 2014, https://www.white house.gov/the-press-office/2014/04/01/remarks-president-aff ordable-care-act, accessed October 13, 2015.

4. Obama.

5. U.S. Department of Health and Human Services, "Key features of the Affordable Care Act by year," http://www.h hs.gov/healthcare/facts/timeline/timeline-text.html, accessed April 21, 2015.

6. U.S. Department of Health and Human Services, "Six out of ten uninsured African Americans may be eligible for Medicaid, CHIP or tax credits in the health insurance marketplace," 2013, http://www.hhs.gov/news/press/2013pr es/12/20131209a.html, accessed May 4, 2015.

7. U.S. Department of Health and Human Services, "The Affordable Care Act and Latinos," November 5, 2014, http:/ /www.hhs.gov/healthcare/facts-and-features/fact-sheets/aca-a nd-latinos/index.html, accessed October 13, 2015.

\section{Obama.}

9. David U. Himmelstein, Elizabeth Warren, Deborah Thorne, and Steffe Woolhandler, "Illness and injury as contributors to bankruptcy," Health Affairs, 2005, Supplementary Web Exclusives: W5-63-W5-73.

10. Paul Pierson, Dismantling the Welfare State? Reagan, Thatcher and the Politics of Retrenchment (Cambridge: Cambridge University Press, 1994), as discussed by Andrea Louise Campbell, "The durability of Pierson's theory about the durability of the welfare state," PS: Political Science \& Politics, 2015, 48(2): 284-288.

11. Pierson, 1994, p. 4.

12. Jacob Hacker, "Privatizing risk without privatizing the welfare state: The hidden politics of social policy retrenchment in the United States," American Political Science Review, 2004, 98(2): 243-260, at pp. 246, 247, 249, 256, $257,258$.

13. Andrea Louise Campbell, How Policies Make Citizens: Senior Political Activism and the American Welfare State (Princeton: Princeton University Press, 2003), p. 2.

14. Paul Pierson, "Increasing returns, path dependence, and the study of politics," American Political Science Review, 2000, 94(2): 251-267, at p. 251.

15. Anne Schneider and Helen Ingram, "Social construction of target populations: Implications for politics and policy," American Political Science Review, 1993, 87(2): 334-347, at pp. $335,338$. 


\section{Press depictions of ACA beneficiaries}

16. Eric M. Patashnik and Julian E. Zelizer, "The struggle to remake politics: Liberal reform and the limits of policy feedback in the contemporary American state," Perspectives on Politics, 2013, 11(4): 1071-1087.

17. Lawrence R. Jacobs and Suzanne Mettler, "Why public opinion changes: The implications for health and health policy," Journal of Health Politics, Policy and Law, 2011, 36(6): 917-933.

18. William M. Sage, "Brand new law! The need to market health care reform," University of Pennsylvania Law Review, 2011, 159(6): 2121-2146.

19. Patashnik and Zelizer, 2013, p. 1072.

20. Patashnik and Zelizer, 2013, pp. 1074, 1079-1081.

21. Campbell, 2003, p. 132.

22. Schneider and Ingram, 1993, p. 334.

23. Theda Skocpol, "Targeting within universalism: Politically viable policies to combat poverty in the United States," in Social Policy in the United States: Future Possibilities in Historical Perspective, Theda Skocpol, ed. (Princeton: Princeton University Press, 1995a), pp. 250-274.

24. Theda Skocpol, Protecting Soldiers and Mothers: The Political Origins of Social Policy in the United States (Cambridge, MA: The Belknap Press of Harvard University Press, 1992), p. 60.

25. Thomas E. Nelson and Donald R. Kinder, "Issue frames and group-centrism in American public opinion," Journal of Politics, 1996, 58(4): 1055-1078, at p. 1074.

26. Campbell, 2003, p. 142 [quote], and chapter 7 generally.

27. Suzanne Mettler, "Bringing the state back in to civic engagement: Policy feedback effects of the G.I. Bill for World War II veterans," American Political Science Review, 2002, 96(2): 351-365.

28. Skocpol, 1992, p. 48.

29. Pierson, 1994, p. 9.

30. Campbell, 2003, pp. 3, 136, 140.

31. Schneider and Ingram, 1993, pp. 335-342.

32. Joe Soss, Richard C. Fording, and Sanford F. Schram, Disciplining the Poor: Neoliberal Paternalism and the Persistent Power of Race (Chicago: University of Chicago Press, 2011), p. 52.

33. Pierson, 1994, p. 30.

34. Suzanne Mettler, The Submerged State: How Invisible Government Policies Undermine American Democracy (Chicago: The University of Chicago Press, 2011), p. 29.
35. Mettler, 2011, p. 28.

36. Patashnik and Zelizer, 2013, pp. 1077, 1079-1080.

37. Campbell, 2003, p. 36.

38. HealthCare.gov, "Medicaid expansion \& what it means for you," https://www.HealthCare.gov/medicaid-chip/medica id-expansion-and-you/, accessed May 10, 2015.

39. Lawrence R. Jacobs, "Health reform and the future of American politics," Perspectives on Politics, 2014, 12(3): 631-642, at p. 632.

40. Jacobs, 2014, p. 632.

41. Carter C. Price and Evan Saltzman, "The economic impact of the Affordable Care Act on Arkansas," RAND Health Research Report, 2013, http://www.rand.org/content /dam/rand/pubs/research_reports/RR100/RR157/RAND_RR 157.pdf.

42. Stan Dorn, John Holahan, Caitlin Carroll, and Megan McGrath, "ACA implementation-Monitoring and tracking. Medicaid expansion under the ACA: How states analyze the fiscal and economic trade-offs," Robert Wood Johnson Foundation and Urban Institute, June 2013, http://www. rwjf.org/content/dam/farm/reports/issue_briefs/2013/ rwjf406481, accessed June 13, 2013.

43. Adele Shartzer, Genevieve M. Kenney, Sharon K. Long, Katherine Hempstead, and Douglas Wissoker, "Who are the remaining uninsured as of June 2014?" Urban Institute Health Policy Center, Health Reform Monitoring Survey, July 29, 2014, http://hrms.urban.org/briefs/who-are-the-rem aining-uninsured-as-of-june-2014.html, accessed August 7, 2014.

44. Lawrence Gostin and Kelli Garcia, "Affordable Care Act litigation: The Supreme Court and the future of health care reform," Journal of the American Medical Association, 2012, 307(4): 369-370.

45. Henry J. Kaiser Family Foundation, "A guide to the Supreme Court's Affordable Care Act decision,” 2012, http:/ /kaiserfamilyfoundation.files.wordpress.com/2013/01/8332. pdf.

46. Henry J. Kaiser Family Foundation, "Current status of state Medicaid expansion decisions, 2014,” 2014, http://kais erfamilyfoundation.files.wordpress.com/2014/03/current-sta tus-of-the-medicaid-expansion-decisions-healthreform1.png, accessed August 17, 2014.

47. National Conference of State Legislatures, "Health insurance exchanges or marketplaces: State profiles and actions," May 9, 2014, http://www.ncsl.org/Portals/1/Docu ments/Health/Health_Insurance_Exchanges_State_Profiles.p df, accessed August 17, 2014. 


\section{Chattopadhyay}

48. Henry J. Kaiser Family Foundation, "State Decisions on Health Insurance Marketplaces and the Medicaid Expansion," as of November 2, 2015, http://kff.org/health-reform/ state-indicator/state-decisions-for-creating-health-insuranceexchanges-and-expanding-medicaid/, accessed November 9, 2015.

49. National Conference of State Legislatures, "Health insurance exchanges or marketplaces: State profiles and actions, Includes information for 2015 enrollment and previews of 2016 plans, As of October 20, 2015," http://ww w.ncsl.org/portals/1/documents/health/health_insurance_exc hanges_state_profiles.pdf, accessed November 10, 2015.

50. Dorn et al., p. 3.

51. Eric Lipton and Sheryl Gay Stolberg, "Health law rollout provides rich target for oversight chief," The New York Times, November 12, 2013, http://www.nytimes.com/2013/ 11/13/us/politics/health-law-rollout-provides-rich-target-foroversight-chief.html, accessed May 4, 2015.

52. Jacobs, 2011, p. 631.

53. U.S. Department of Health and Human Services, Office of the Assistant Secretary for Planning and Evaluation, "Health insurance marketplace: Summary enrollment report for the initial annual open enrollment period," May 1, 2014 , http://aspe.hhs.gov/health/reports/2014/marketplaceenrollm ent/apr2014/ib_2014apr_enrollment.pdf, accessed April 18, 2015 , p. 16.

54. Skocpol, 1995a, p. 259.

55. Jacobs, 2011, pp. 625-627.

56. Lawrence R. Jacobs and Theda Skocpol, Health Care Reform and American Politics: What Everyone Needs to Know, revised edition (New York: Oxford University Press, 2012), p. 5 .

57. Patashnik and Zelizer, 2013, p. 1080.

58. Theda Skocpol, "The political challenges that may undermine health reform," Health Affairs, 2010, 29(7): $1288-1292$, at p. 1290

59. Skocpol, 2010, p. 1290.

60. U.S. Department of Health and Human Services, "Key features of the Affordable Care Act by year."

61. Robert Wood Johnson Foundation, "How does the Affordable Care Act address racial and ethnic disparities in health care?" Health Policy Snapshot, Disparities, Issue Brief, December 2011, http://www.rwjf.org/content/dam/far m/reports/issue_briefs/2011/rwjf71997, accessed August 12, 2015 .

62. U.S. Department of Health and Human Services, "Key features of the Affordable Care Act by year.”
63. Jacobs and Skocpol, p. 5.

64. Michael D. Shear, "Obama urges focus on health care law's benefits," The New York Times, December 4, 2013, h ttp://www.nytimes.com/2013/12/04/us/politics/obama-urge s-focus-on-health-care-laws-benefits.html, accessed May 4, 2015.

65. Jacobs and Skocpol, p. 122, original emphasis.

66. Skocpol, 1992, pp. 33, 60.

67. Michael B. Katz, The Undeserving Poor: America's Enduring Confrontation with Poverty, 2nd edition (New York: Oxford University Press, 2013), pp. 139-140.

68. Campbell, 2003, pp. 7, 141.

69. Skocpol, 1995a, p. 253.

70. Campbell, 2003, p. 7.

71. Margaret Weir, Ann Shola Orloff, and Theda Skocpol, "Epilogue: The future of social policy in the United States: Political constraints and possibilities," in The Politics of Social Policy in the United States, Margaret Weir, Ann Shola Orloff, and Theda Skocpol, eds. (Princeton: Princeton University Press, 1988a), pp. 421-445, at pp. 437, 441.

72. Theda Skocpol, "State formation and social policy in the United States," in Social Policy in the United States: Future Possibilities in Historical Perspective, Theda Skocpol, ed. (Princeton: Princeton University Press, 1995b), pp. 11-36, at p. 32.

73. Pierson, 1994, p. 55.

74. Theda Skocpol, "Introduction: American social policies: Future possibilities in historical perspective," in Social Policy in the United States: Future Possibilities in Historical Perspective, Theda Skocpol, ed. (Princeton: Princeton University Press, 1995c), pp. 3-10, at p. 7.

75. Jonathan Oberlander, The Political Life of Medicare (Chicago: The University of Chicago Press, 2003), p. 5.

76. Laura Katz Olson, The Politics of Medicaid (New York: Columbia University Press, 2010), p. 6.

77. Kathryn M. Neckerman, Robert Aponte, and William Julius Wilson, "Family structure, black unemployment, and American social policy," in The Politics of Social Policy in the United States, Margaret Weir, Ann Shola Orloff, and Theda Skocpol, eds. (Princeton: Princeton University Press, 1988), pp. 397-419, at p. 418.

78. Robert Greenstein, "Universal and targeted approaches to relieving poverty: An alternative view," in The Urban Underclass, Christopher Jencks and Paul E. Peterson, eds. (Washington, DC: The Brookings Institution, 1991), pp. 437-459, at p. 449. 


\section{Press depictions of ACA beneficiaries}

79. Mettler, 2011, pp. 108, 118.

80. Campbell, 2003, p. 55.

81. Mettler, 2011, p. 32.

82. Pierson, 1994 , p. 45.

83. Mettler, 2011, p. 35.

84. Mettler, 2011, p. 113.

85. Mettler, 2011, pp. 71, 81.

86. Patashnik and Zelizer, 2013, p. 1079.

87. Pierson, 1994, p. 27.

88. Schneider and Ingram, 1993.

89. Nicholas Winter, "Beyond welfare: Framing and the racialization of white opinion on Social Security," American Journal of Political Science, 2006, 50(2): 400-420.

90. Oberlander, p. 79.

91. Margaret Weir, Ann Shola Orloff, and Theda Skocpol, "Part I: Institutional limits and patterns of policy," in The Politics of Social Policy in the United States, Margaret Weir, Ann Shola Orloff, and Theda Skocpol, eds. (Princeton: Princeton University Press, 1988b), pp. 29-35, at p. 35; Weir, Orloff, and Skocpol, 1988a, pp. 431, 437.

92. Patashnik and Zelizer, 2013, pp. 1072, 1074.

93. Pierson, 1994, p. 50.

94. Margaret Weir, Ann Shola Orloff, and Theda Skocpol, "Part II: Transformations within the New Deal system," in The Politics of Social Policy in the United States, Margaret Weir, Ann Shola Orloff, and Theda Skocpol, eds. (Princeton: Princeton University Press, 1988c), pp. 191-197, at p. 193; Margaret Weir, Ann Shola Orloff, and Theda Skocpol, "Part III: Social policy, race, and the "poverty problem," in The Politics of Social Policy in the United States, Margaret Weir, Ann Shola Orloff, and Theda Skocpol, eds. (Princeton: Princeton University Press, 1988d), pp. 285-291, at pp. 290, 291.

95. Kenneth Finegold, "Agriculture and the politics of U.S. social provision: Social insurance and food stamps," in The Politics of Social Policy in the United States, Margaret Weir, Ann Shola Orloff, and Theda Skocpol, eds. (Princeton: Princeton University Press, 1988), pp. 199-234, at p. 200.

96. John Myles, "Postwar capitalism and the extension of Social Security into a retirement wage," in The Politics of Social Policy in the United States, Margaret Weir, Ann Shola Orloff, and Theda Skocpol, eds. (Princeton: Princeton University Press, 1988), pp. 265-284, at p. 283.
97. Patashnik and Zelizer, 2013, pp. 1072, 1074.

98. Skocpol, 1992, p. ix [quote]; see also pp. 2, 17, 55, 428, $482,530,537$.

99. Jill Quadagno, "From Old-Age Assistance to Supplemental Security Income: The political economy of relief in the South, 1935-1972," in The Politics of Social Policy in the United States, Margaret Weir, Ann Shola Orloff, and Theda Skocpol, eds. (Princeton: Princeton University Press, 1988), pp. 235-263, at pp. 236, 263.

100. Finegold, p. 232.

101. Pierson, 1994, p. 166.

102. Greenstein, pp. 450-452.

103. Patashnik and Zelizer, 2013.

104. Eric M. Patashnik and Julian E. Zelizer, "When policy does not remake politics: The limits of policy feedback," (Unpublished manuscript, Toronto: APSA 2009 Meeting Paper, 2009), http://papers.ssrn.com/sol3/papers.cfm?abstrac t_id=1449996.

105. Schneider and Ingram, 1993, pp. 340-346, Table 1.

106. Helen M. Ingram and Anne L. Schneider, "Introduction: Public policy and the social construction of deservedness," in Deserving and Entitled: Social Constructions and Public Policy, Anne L. Schneider and Helen M. Ingram, eds. (Albany: State University of New York Press, 2005a), pp. 1-28, at pp. 19-27.

107. Joe Soss, "Lessons of welfare: Policy design, political learning, and political action," American Political Science Review, 1999, 93(2): 363-380, especially p. 368.

108. Patashnik and Zelizer, 2013, p. 1075.

109. Shanto Iyengar, "Framing responsibility for political issues: The case of poverty," Political Behavior, 1990, 12(1): 19-40, at p. 36.

110. Nelson and Kinder, p. 1072.

111. Nelson and Kinder, p. 1056.

112. Nelson and Kinder.

113. Soss, p. 368.

114. Soss, Fording, and Schram, p. 293.

115. Soss, Fording, and Schram, pp. 38, 120-123.

116. Skocpol, 2010.

117. Jacobs and Skocpol, pp. 7, 9. 


\section{Chattopadhyay}

118. Patashnik and Zelizer, 2013, p. 1080.

119. Jacobs, 2010, p. 621.

120. Skocpol, 2010, p. 1291.

121. Jacobs, 2010, pp. 619, 622, 623.

122. Patashnik and Zelizer, 2013, p. 1079.

123. Sheryl Gay Stolberg and Michael D. Shear, "Inside the race to rescue a health site, and Obama," The New York Times, December 1, 2013, http://www.nytimes.com/2013/12 /01/us/politics/inside-the-race-to-rescue-a-health-site-and-oba ma.html, accessed May 4, 2015.

124. Price and Saltzman, pp. 1, 2, 9.

125. Price and Saltzman, pp. 1, 2, 9.

126. Dorn et al.

127. Lisa Dubay, John Holahan, Sharon K. Long, and Emily Lawton, "Will the Affordable Care Act be a job killer?," Urban Institute, October 2012, http://www.urban.o rg/UploadedPDF/412684-Will-the-Affordable-Care-Act-Be-a -Job-Killer.pdf, accessed June 13, 2013.

128. "Some states have second thoughts about refusing Medicaid expansion,” PBS Newshour, June 17, 2013, http:// www.pbs.org/newshour/bb/government_programs-jan-june1 3-medicaid_06-17/, accessed August 21, 2014.

129. Sean Nicholson-Crotty, "Leaving money on the table: Learning from recent refusals of federal grants in the American states," Publius, 2012, 42(3): 449-466.

130. Soss, p. 368 .

131. Mettler, 2002, p. 360.

132. Lisa Miller, "CMS to offer school breakfasts to all children," WFAE 90.7 Charlotte's NPR News Source, June 12, 2013, http://www.wfae.org/post/cms-offer-school-breakf asts-all-children [transcript].

133. Katherine S. Newman, No Shame in My Game: The Working Poor in the Inner City (New York: Vintage Books and Russell Sage Foundation, 1999), pp. 22, 98.

134. Kenneth J. Neubeck and Noel A. Cazenave, Welfare Racism: Playing the Race Card Against America's Poor (New York: Routledge, 2001), p. 108.

135. Mettler, 2011, p. 112.

136. William G. Jacoby, "Issue framing and public opinion on government spending," American Journal of Political Science, 2000, 44(4): 750-767, at p. 752.

137. Oberlander, p. 68.
138. Patashnik and Zelizer, 2013, p. 1078.

139. Campbell, 2003, pp. 85, 94-95, 98.

140. Martin Gilens, Why Americans Hate Welfare: Race, Media, and the Politics of Antipoverty Policy (Chicago:

University of Chicago Press, 1999).

141. Dennis Chong, "Creating common frames of reference on political issues," in Political Persuasion and Attitude Change, Diana C. Mutz, Paul M. Sniderman, and Richard A. Brody, eds. (Ann Arbor: University of Michigan Press, 1996), pp. 195-224, at p. 199.

142. Martin Gilens, "'Race coding' and white opposition to welfare," American Political Science Review, 1996, 90(3): 593-604.

143. Hector P. Rodriguez, Mariam J. Laugesen, and Carolyn A. Watts, "A randomized experiment of issue framing and voter support of tax increases for health insurance expansion," Health Policy, 2010, 98(2-3): 245-255, at p. 245 .

144. Campbell, 2003, p. 132.

145. Campbell, 2003, p. 132.

146. Oberlander, p. 140 [quote]; see also p. 143.

147. Pierson, 1994, p. 66.

148. Schneider and Ingram, 1993, pp. 335-340.

149. Sean Nicholson-Crotty and Kenneth J. Meier, "From perception to public policy: Translating social constructions into policy designs," in Deserving and Entitled: Social Constructions and Public Policy, Anne L. Schneider and Helen M. Ingram, eds. (Albany: State University of New York Press, 2005), pp. 223-242, at p. 223.

150. Max Rose and Frank R. Baumgartner, "Framing the poor: Media coverage and U.S. poverty policy, 1960-2008," Policy Studies Journal, 2013, 41(1): 22-53, at p. 22.

151. Oberlander, p. 72[quote]; see also pp. 62-65, 165167.

152. Schneider and Ingram, 1993, pp. 335, 340-342.

153. Soss, p. 368.

154. Patashnik and Zelizer, 2013, pp. 1077, 1078.

155. Schneider and Ingram, 1993, pp. 340-346 and Table 1.

156. Ingram and Schneider, 2005a, pp. 19-27.

157. Campbell, 2003.

158. Mettler, 2002, pp. 356-358. 


\section{Press depictions of ACA beneficiaries}

159. Campbell, 2003, p. 2.

160. Campbell, 2003, p. 139.

161. Patashnik and Zelizer, 2009, p. 17.

162. Soss, p. 376.

163. Soss.

164. Schneider and Ingram, 1993, p. 339.

165. Soss, Fording, and Schram, pp. 249-251.

166. Ingram and Schneider, 2005a, p. 19.

167. Ingram and Schneider, 2005a, p. 19.

168. Campbell, 2003, p. 137.

169. James N. Druckman, "The implications of framing effects for citizen competence," Political Behavior, 2001a, 23(3): 225-256, at pp. 227-228.

170. Dennis Chong and James N. Druckman, "Framing theory," Annual Review of Political Science, 2007a, 10(1): 103-126, at pp. 105-106.

171. Dennis Chong and James N. Druckman, "A theory of framing and opinion formation in competitive elite environments," Journal of Communication, 2007b, 57(1): 99-118, at pp. 100-101.

172. Druckman, 2001a, p. 228.

173. Thomas E. Nelson, Zoe M. Oxley, and Rosalee A. Clawson, "Toward a psychology of framing effects," Political Behavior, 1997, 19(3): 221-246, at p. 221.

174. Druckman, 2001a, pp. 226-227.

175. James N. Druckman, "On the limits of framing effects: Who can frame?," Journal of Politics, 2001b, 63(4): 1041-1066, at p. 1042.

176. Michael Binder, Matthew Childers, and Natalie Johnson, "Campaigns and the mitigation of framing effects on voting behavior: A natural and field experiment," Political Behavior, 2015, 37(3): 703-722, at p. 704.

177. Nelson, Oxley, and Clawson, p. 236.

178. Nelson and Kinder, p. 1074.

179. Chong and Druckman, 2007a, p. 114.

180. Druckman, 2001a, p. 230.

181. Eran N. Ben-Porath and Lee K. Shaker, "News images, race, and attribution in the wake of Hurricane Katrina," Journal of Communication, 2010, 60(3): 466-490, at pp. 468, 471.
182. Carl L. Palmer, "The influence of group and outcome cues on perceptions of governmental spending," (Unpublished manuscript, Notre Dame, IN: University of Notre Dame: Department of Political Science, 2011a), http://ssrn.com/abstract=1464454, accessed April 18, 2015, pp. 2,3 .

183. Carl L. Palmer, "A tale of two cues: The impact of subliminal and implicit appeals for racialized issue opinion," (Unpublished manuscript, Notre Dame, IN: University of Notre Dame: Department of Political Science, 2011b), htt p://papers.ssrn.com/sol3/papers.cfm?abstract_id=1902773, accessed April 18, 2015, pp. 4-5.

184. Tali Mendelberg, "Racial priming revived," Perspectives on Politics, 2008, 6(1): 109-123.

185. Nelson and Kinder, p. 1074.

186. Jacoby, pp. 751-752.

187. Nelson and Kinder, p. 1055.

188. Palmer, 2011a, p. 4.

189. Helen M. Ingram and Anne L. Schneider, "Part IV: Constructions by moral entrepreneurs and policy analysts," in Deserving and Entitled: Social Constructions and Public Policy, Anne L. Schneider and Helen M. Ingram, eds. (Albany: State University of New York Press, 2005b), pp. 219-221, at pp. 219-220.

190. Jacoby, pp. 750-751, 764.

191. Chong, p. 199.

192. James N. Druckman, "Political preference formation: Competition, deliberation, and the (ir)relevance of framing effects," American Political Science Review, 2004, 98(4): 671-686.

193. Dennis Chong and James N. Druckman, "Framing public opinion in competitive democracies," American Political Science Review, 2007c, 101(4): 637-655.

194. Chong and Druckman, 2007a, pp. 111-113.

195. Chong and Druckman, 2007b, pp. 102-105, 107.

196. Palmer, 2011a, pp. 13, 20.

197. Ben-Porath and Shaker, pp. 468, 471.

198. Jacobs and Mettler, p. 926.

199. Nelson, Oxley, and Clawson, pp. 227-228, 236.

200. Soss, p. 368.

201. Binder, Childers and Johnson, p. 3. 


\section{Chattopadhyay}

202. Amos Tversky and Daniel Kahneman, "Advances in prospect theory: Cumulative representation of uncertainty," in Choices, Values, and Frames, Daniel Kahneman and Amos Tversky, eds. (New York: Russell Sage Foundation and Cambridge University Press, 2000), pp. 44-65, at p. 45.

203. Schneider and Ingram, 1993, p. 343.

204. Helen Ingram and Anne L. Schneider, "Social construction (continued): Response," American Political Science Review, 1995, 89(2): 441-446, at p. 443.

205. Gilens, 1999, pp. 133-139, 153, 206.

206. Kent A. Ono and John M. Sloop, Shifting Borders: Rhetoric, Immigration, and California's Proposition 187 (Philadelphia: Temple University Press, 2002), p. 6.

207. Shanto Iyengar, Mark D. Peters, and Donald R. Kinder, "Experimental demonstrations of the "not-sominimal' consequences of television news programs," American Political Science Review, 1982, 76(4): 848-858, at p. 848 .

208. Nelson, Oxley, and Clawson, p. 221.

209. Ingram and Schneider, 2005a, p. 5.

210. Patashnik and Zelizer, 2013, pp. 1075, 1076, Table 1.

211. Patashnik and Zelizer, 2009, p. 38, Table 1.

212. Stephanie J. DiAlto, “From 'problem minority' to 'model minority': The changing social construction of Japanese Americans," in Deserving and Entitled: Social Constructions and Public Policy, Anne L. Schneider and Helen M. Ingram, eds. (Albany: State University of New York Press, 2005), pp. 81-103, at p. 82.

213. Jacoby.

214. Druckman, 2001b, p. 1061.

215. John Zaller, "The myth of massive media impact revived: New support for a discredited idea," in Political Persuasion and Attitude Change, Diana C. Mutz, Paul M. Sniderman, and Richard A. Brody, eds. (Ann Arbor: University of Michigan Press, 1996), pp. 17-78, at p. 18 [quote]; see also pp. 59, 60.

216. Timothy E. Cook, Governing with the News: The News Media as Political Institution (Chicago: The University of Chicago Press, 1998), p. 11 [quote]; see also p. 140.

217. Jacoby, p. 751.

218. Cook, p. 87.

219. Cook, p. 3.
220. W. Lance Bennett and Shanto Iyengar, “A new era of minimal effects? The changing foundations of political communication," Journal of Communication, 2008, 58(4): 707-731, at p. 725 .

221. Bennett and Iyengar, p. 707.

222. Iyengar, Peters and Kinder, p. 848.

223. Ben-Porath and Shaker, p. 466.

224. Elizabeth M. Armstrong, Daniel P. Carpenter, and Marie Hojnacki, "Whose deaths matter? Mortality, advocacy, and attention to disease in the mass media," Journal of Health Politics, Policy and Law, 2006, 31(4): 729-772, at p. 768.

225. Chong, p. 196.

226. Iyengar, p. 21.

227. Nelson, Oxley, and Clawson, p. 236.

228. Gilens, 1999, pp. 121-125, 145.

229. DiAlto, p. 84.

230. DiAlto, p. 84.

231. Soss, p. 368.

232. Weir, Orloff, and Skocpol, 1988a, pp. 437, 441.

233. William Julius Wilson, "Public Policy Research and The Truly Disadvantaged," in The Urban Underclass, Christopher Jencks and Paul E. Peterson, eds. (Washington, DC: The Brookings Institution, 1991), pp. 460-481, at p. 478.

234. Skocpol, 1992, p. 60.

235. Skocpol, 1995b, p. 32.

236. Skocpol, 1995a.

237. Oberlander, pp. 79-80.

238. Greenstein, p. 449.

239. Campbell, 2003, p. 7.

240. Schneider and Ingram, 1993, pp. 335-336.

241. Skocpol, 1992, pp. 33, 60.

242. Weir, Orloff, and Skocpol, 1988a, p. 430, original emphasis.

243. Patashnik and Zelizer, 2013, p. 1079.

244. Patashnik and Zelizer, 2013, p. 1079. 


\section{Press depictions of ACA beneficiaries}

245. Skocpol, 1992, p. 59.

246. Campbell, 2015, p. 284.

247. Campbell, 2003, p. 142.

248. Campbell, 2003, p. 36.

249. Jacobs and Mettler, p. 928.

250. Jacobs, 2011, p. 629.

251. Jacobs, 2014, p. 636.

252. Patashnik and Zelizer, 2013, p. 1079.

253. Benjamin D. Sommers, Thomas Buchmueller, Sandra L. Decker, Colleen Carey, and Richard Kronick, "The Affordable Care Act has led to significant gains in health insurance and access to care for young adults," Health Affairs, 2013, 32(1): 165-174.

254. U.S. Department of Health and Human Services, "HHS launches partnership and video contest with young invincibles," August 19, 2013, http://www.hhs.gov/news/pre ss/2013pres/08/20130819a.html, accessed May 4, 2015.

255. Patashnik and Zelizer, 2013, p. 1079.

256. Campbell, 2003.

257. Skocpol, 1992, p. 48.

258. Anne L. Schneider and Helen M. Ingram, eds., Deserving and Entitled: Social Constructions and Public Policy

(Albany: State University of New York Press, 2005a).

259. Soss, Fording, and Schram, pp. 85, 235.

260. Katz.

261. Gilens, 1999, pp. 66, 205.

262. Skocpol, 1992, p. 149.

263. Winter.

264. Campbell, 2003, p. 138.

265. Skocpol, 1992, pp. 266-267.

266. Soss.

267. Ingram and Schneider, 1995, p. 443.

268. Gilens, 1999, p. 111.

269. Schneider and Ingram, 1993, p. 336, Figure 1.

270. Schneider and Ingram, 1993, p. 335.

271. Linda Gordon, The Great Arizona Orphan Abduction (Cambridge, MA: Harvard University Press, 2001), as cited by Soss, Fording, and Schram, p. 85.
272. Soss, Fording, and Schram, p. 85.

273. Claire Jean Kim, "The racial triangulation of Asian

Americans," Politics \& Society, 1999, 27(1): 105-138.

274. Soss, Fording, and Schram, p. 85; see also pp. 22, 23, 43-44, 46, 233.

275. Frances Fox Piven and Richard A. Cloward, Regulating the Poor: The Functions of Public Welfare, updated edition (New York: Vintage Books, 1993), pp. 382, 396.

276. Gilens, 1999, pp. 3, 37, 64, 77.

277. Katz, pp. $185,198$.

278. Skocpol, 1995 c, p. 7.

279. Theda Skocpol, "The limits of the New Deal system and the roots of contemporary welfare dilemmas," in Social Policy in the United States: Future Possibilities in Historical Perspective, Theda Skocpol, ed. (Princeton: Princeton University Press, 1995d), pp. 209-227, at p. 213.

280. G. John Ikenberry and Theda Skocpol, "The road to Social Security," in Social Policy in the United States: Future Possibilities in Historical Perspective, Theda Skocpol, ed. (Princeton: Princeton University Press, 1995), pp. 136-166, at pp. 162, 163.

281. Newman, p. 87.

282. Piven and Cloward, p. 448.

283. Katz, p. 3.

284. Ingram and Schneider, 2005b, p. 221.

285. Gilens, 1999, p. 149.

286. Ingram and Schneider, 2005a, p. 17.

287. Edwin Amenta and Theda Skocpol, "Redefining the New Deal: World War II and the development of social provision in the United States," in Social Policy in the United States: Future Possibilities in Historical Perspective, Theda Skocpol, ed. (Princeton: Princeton University Press, 1995), pp. 167-208, at pp. 168, 206.

288. Rodriguez, Laugesen, and Watts, p. 245.

289. Schneider and Ingram, 1993, p. 336, Figure 1.

290. Skocpol, 1992, pp. 135, 149-150.

291. Laura S. Jensen, “Constructing and entitling America's original veterans," in Deserving and Entitled: Social Constructions and Public Policy, Anne L. Schneider and Helen M. Ingram, eds. (Albany: State University of New York Press, 2005), pp. 35-62, at p. 36. 


\section{Chattopadhyay}

292. Kim, p. 118.

293. Schneider and Ingram, 1993, p. 339.

294. Ingram and Schneider, 2005a, p.17.

295. Schneider and Ingram, 1993, p. 341.

296. Soss, Fording, and Schram, p. 203.

297. Soss, p. 368.

298. Soss, Fording, and Schram, p. 22.

299. Kay Schriner, "Constructing the democratic citizen: Idiocy and insanity in American suffrage law," in Deserving and Entitled: Social Constructions and Public Policy, Anne L. Schneider and Helen M. Ingram, eds. (Albany: State University of New York Press, 2005), pp. 63-80, at p. 77.

300. Gilens, 1999, p. 37.

301. Gilens, 1999.

302. Piven and Cloward, p. 169.

303. Jill Quadagno, The Color of Welfare: How Racism Undermined the War on Poverty (New York: Oxford University Press, 1994), pp. 120-121.

304. Newman, p. 98.

305. Soss, Fording, and Schram, p. 52 [quote]; see also pp. $40,95$.

306. Ingram and Schneider, 2005a, p.17.

307. Skocpol, 1992, p. 471.

308. Schneider and Ingram, 1993, pp. 336, 343.

309. Katz, p. 9.

310. Winter, p. 402.

311. Soss, Fording, and Schram, p. 85.

312. Winter, p. 405, original emphasis.

313. Winter, p. 405.

314. Ono and Sloop, pp. 70-71.

315. Edward G. Carmines and James A. Stimson, Issue Evolution: Race and the Transformation of American Politics (Princeton: Princeton University Press, 1989).

316. Piven and Cloward, p. 423.

317. Tali Mendelberg, "Executing Hortons: Racial crime in the 1988 presidential campaign," Public Opinion Quarterly, 1997, 61(1): 134-157.
318. Tali Mendelberg, The Race Card: Campaign Strategy, Implicit Messages, and the Norm of Equality (Princeton: Princeton University Press, 2001).

319. Neubeck and Cazenave, pp. 126, 148.

320. Schneider and Ingram, 1993, p. 336, Figure 1.

321. Ingram and Schneider, 2005a, p. 17.

322. Gilens, 1999, pp. 125-127, 129.

323. Ono and Sloop, pp. 28-29, 39.

324. Neubeck and Cazenave, pp. 34-35, 110-111, 139141.

325. Kim, pp. 110, 118, 128.

326. Joshua L. Rabinowitz, David O. Sears, Jim Sidanius, and Jon A. Krosnick, "Why do white Americans oppose race-targeted policies? Clarifying the impact of symbolic racism," Political Psychology, 2009, 30(5): 805-828, at pp. $805,819,825$.

327. Christopher D. DeSante, "Working twice as hard to get half as far: Race, work ethic, and America's deserving poor," American Journal of Political Science, 2013, 57(2): 342-356.

328. Neubeck and Cazenave, p. 36.

329. Winter, pp. 400, 404.

330. Gilens, 1999, pp. 3, 5, 72, 80, 92, 214-215.

331. Soss, Fording, and Schram, pp. 62, 65.

332. DeSante.

333. Soss, Fording, and Schram, pp. 100-101, 126, 136, 137, 140, 175.

334. Kim, p. 108, Figure 1.

335. Otto Santa Ana, Brown Tide Rising: Metaphors of Latinos in Contemporary American Public Discourse (Austin, TX: University of Texas Press, 2002).

336. Jennifer Hochschild, Jacqueline Chattopadhyay, Claudine Gay, and Michael Jones-Correa, eds., Outsiders No More? Models of Immigrant Political Incorporation (New York: Oxford University Press, 2013).

337. Katz, p. 9.

338. Anne L. Schneider and Helen M. Ingram, "Part II: Congressional discourse: Forging lines of division between deserving and undeserving," in Deserving and Entitled: Social Constructions and Public Policy, Anne L. Schneider and Helen M. Ingram, eds. (Albany: State University of New York Press, 2005b), pp. 105-110, at p. 110. 


\section{Press depictions of ACA beneficiaries}

339. Kim.

340. Soss, Fording, and Schram, p. 14.

341. Soss, Fording, and Schram, p. 131.

342. Soss, Fording, and Schram, p. 4, original emphasis.

343. Soss, Fording, and Schram, pp. 80, 260.

344. Gilens, 1999, p. 206, emphasis added.

345. Mendelberg, 2001.

346. Kim, p. 117.

347. Gilens, 1996, p. 593.

348. Winter, p. 403.

349. Katz, pp. 9, 85, 225.

350. Piven and Cloward, pp. 123, 124, 129-130.

351. Skocpol, 1992, p. 2 [quote]; see also pp. 10, 21, 317, 333, 337.

352. Schneider and Ingram, 1993, p. 336, Figure 1.

353. Skocpol, 1992, p. 96.

354. Skocpol, 1992, p. 32.

355. Katz, pp. 21-22, 87, 92, 98.

356. Piven and Cloward, pp. 136, 346.

357. Soss, Fording, and Schram, pp. 56, 61, 87-88, 95, 259.

358. Neubeck and Cazenave, pp. 28-35.

359. Skocpol, 1992, pp. 467-470.

360. Katz, pp. $8,11,86$.

361. Skocpol, 1992, pp. 32, 467.

362. Iyengar, p. 36.

363. Theda Skocpol, "Conclusion: Remaking U.S. social policies for the 21st century," in Social Policy in the United States: Future Possibilities in Historical Perspective, Theda Skocpol, ed. (Princeton: Princeton University Press, 1995e), pp. 297-312, at pp. 304, 310.

364. Katz, pp. 3, 88, 265, 269.

365. Rodriguez, Laugesen, and Watts, p. 245.

366. Schneider and Ingram, 1993, p. 336, Figure 1.

367. Schneider and Ingram, 1993, p. 336, Figure 1.
368. Quadagno, 1994, pp. 165-166.

369. Schneider and Ingram, 1993, pp. 336, 339, and Figure 1.

370. Schriner, pp. 66-67.

371. Jaclyn S. Piatak, "Understanding the implementation of Medicare and Medicaid: Social construction and historical context," Administration \& Society, 2015, Online First: $1-26$, at p. 7.

372. Kim, p. 118.

373. Quadagno, 1994, pp. 117, 124.

374. Skocpol, 1992, p. 467.

375. Katz, p. 18.

376. Schneider and Ingram, 1993, p. 336, Table 1.

377. Kim, Table 1, p. 121.

378. Katz, pp. 1-2.

379. Ingram and Schneider, 2005a, pp. 8, 16.

380. Lina Newton, "'It is not a question of being antiimmigration': Categories of deservedness in immigration policy making," in Deserving and Entitled: Social Constructions and Public Policy, Anne L. Schneider and Helen M. Ingram, eds. (Albany: State University of New York Press, 2005), pp. 139-167, at p. 141.

381. Skocpol, 1992, p. 149.

382. Soss, Fording, and Schram, p. 55.

383. DiAlto.

384. Jensen, pp. $35,37$.

385. Oberlander, p. 72.

386. Winter, p. 402.

387. Neubeck and Cazenave, p. 31.

388. DeSante, p. 342.

389. Gilens, 1999, p. 154-158.

390. Winter, p. 402.

391. Kim.

392. Jacobs, 2014, p. 631.

393. Gilens, 1999, pp. 6, 111.

394. Rose and Baumgartner. 


\section{Chattopadhyay}

395. Santa Ana.

396. Ono and Sloop.

397. James N. Druckman, "Media matter: How newspapers and television news cover campaigns and influence voters," Political Communication, 2005, 22(4): 463-481, at p. 463.

398. Lloyd Chiasson, "Japanese-American relocation during World War II: A study of California editorial reactions," Journalism Quarterly, 1991, 68(1-2): 263-268, as cited by DiAlto, p. 85.

399. Schneider and Ingram, 1993, pp. 335, 346.

400. Oberlander, p. 79.

401. U.S. Department of Health and Human Services, "Key features of the Affordable Care Act by year."

402. U.S. Department of Health and Human Services, "Key features of the Affordable Care Act by year."

403. Patashnik and Zelizer, 2013, p. 1080.

404. See U.S. Department of Health and Human Services, "Key features of the Affordable Care Act by year."

405. Robert Pear, "Troubleshooter reports progress and barriers in bid to repair health portal," The New York Times, November 2, 2013, http://www.nytimes.com/2013/11/02/us/ politics/day-1-on-healthcaregov-fewer-than-a-dozen-signed-u p.html, accessed May 4, 2015.

406. Clay Johnson and Harper Reed, "Why the government never gets tech right," The New York Times, October 24, 2013, http://www.nytimes.com/2013/10/25/opinion/gettingto-the-bottom-of-healthcaregovs-flop.html, accessed May 4, 2015.

407. Amy Goldstein, "Timeline of major change to the Affordable Care Act," The Washington Post, March 8, 2014, http://www.washingtonpost.com/national/health-scien ce/timeline-of-major-change-to-the-affordable-care-act/2014/ 03/08/10859e88-a630-11e3-a5fa-55f0c77bf39c_story.html, accessed April 21, 2015.

408. U.S. Department of Health and Human Services, "Administration takes steps to ensure Americans signing up through the marketplace have coverage and access to the care they need on January 1," 2013, http://www.hhs.gov/n ews/press/2013pres/12/20131212a.html, accessed May 4, 2015 .

409. Michael D. Shear and Robert Pear, "Day is added to deadline as rush hits health portal," The New York Times, December 24, 2013, http://www.nytimes.com/2013/12/24/us /deadline-for-health-care-sign-up-is-extended-by-a-day.html, accessed May 4, 2015.
410. John R. Zaller, The Nature and Origins of Mass Opinion (New York: Cambridge University Press, 1992), pp. $42-51$.

411. David Blumenthal and David Squires, "Residents in the ACA's nonparticipating states still benefiting," The Commonwealth Fund blog, May 28, 2015, www.commonw ealthfund.org/publications/blog/2014/may/affordable-care-ac ts-nonparticipating-states, accessed July 27, 2015.

412. Justin Grimmer and Brandon M. Stewart, "Text as data: The promise and pitfalls of automated content analysis methods for political texts," Political Analysis, 2013, 21(3): 267-297, at p. 272.

413. Christopher Lucas, Richard A. Nielsen, Margaret E. Roberts, Brandon M. Stewart, Alex Storer, and Dustin Tingley, "Computer-assisted text analysis for comparative politics," Political Analysis, 2015, 23(2): 254-277, at pp. 257, 259, 260.

414. Grimmer and Stewart, p. 272.

415. Grimmer and Stewart, pp. 272-273.

416. Lucas et al., p. 257.

417. Lucas et al., p. 258.

418. Grimmer and Stewart, p. 273.

419. Lucas et al., p. 258.

420. Winter, p. 405.

421. Grimmer and Stewart, pp. 274, 287, although here the goal is not to classify documents.

422. Adele Shartzer, Sharon K. Long, and Stephen Zuckerman, "Who are the newly insured as of early March 2014?" Urban Institute, Health Reform Monitoring Survey, May 22, 2014, http://hrms.urban.org/briefs/Who-Are-the-Newly-Insu red.html, accessed August 9, 2014.

423. Jacobs and Skocpol, p. 122.

424. Patashnik and Zelizer, 2013, p. 1079.

425. U.S. Department of Health and Human Services, Office of the Assistant Secretary for Planning and Evaluation, "Health insurance marketplace: Summary enrollment report for the initial annual open enrollment period," May 1, 2014, https://aspe.hhs.gov/sites/default/files/pdf/7687 6/ib_2014Apr_enrollment.pdf, p. 1.

426. Campbell, 2015, p. 284.

427. U.S. Department of Health and Human Services, "Key features of the Affordable Care Act by year." 


\section{Press depictions of ACA beneficiaries}

428. Jacobs, 2014, p. 637.

429. Jacobs and Skocpol, p. 44.

430. U.S. Department of Health and Human Services, "Key features of the Affordable Care Act by year.”

431. U.S. Department of Health and Human Services, Office of the Assistant Secretary for Planning and Evaluation, p. 8.

432. Gilens, 1999, pp. 68, 99, 101, 139.

433. Soss, Fording, and Schram, p. 63.

434. U.S. Department of Health and Human Services, Office of the Assistant Secretary for Planning and Evaluation, p. 32.

435. U.S. Department of Health and Human Services, "Enrollment in the health insurance marketplace totals over 8 million people," 2014, http://www.hhs.gov/news/press/201 4pres/05/20140501a.html, accessed May 4, 2015.

436. U.S. Department of Health and Human Services, Office of the Assistant Secretary for Planning and Evaluation, p. 27.

437. Ingram and Schneider, 2005a, p. 17.

438. Ryan D. Enos, "The effect of proximity to African-Americans on Latino vote choice in the 2008 presidential primary in Los Angeles," http://people.hmdc. harvard.edu/ renos/papers/threat_LosAngeles_primary.pdf, accessed July 28, 2015.

439. Mendelberg, 2008, p. 110.

440. Hacker, p. 246.

441. Pierson, 1994, p. 127.

442. Ingram and Schneider, 2005b, pp. 219-220.

443. Fay Lomax Cook and Edith J. Barrett, Support for the American Welfare State: The Views of Congress and the Public (New York: Columbia University Press, 1992), pp. 96-108.

444. Henry J. Kaiser Family Foundation. Public's Views About Medicaid Survey, Apr, 2005 [survey question]. USPSRA.05MEDICAID.R15A. Princeton Survey Research Associates International [producer]. Storrs, CT: Roper Center for Public Opinion Research, iPOLL [distributor], accessed April 21, 2015.

445. Robert Wood Johnson Foundation and Harvard School of Public Health. American Attitudes Toward Health Care Reform, Mar, 1993 [survey question]. USMARTIL.93RWJ.R053. Marttila \& Kiley [producer]. Storrs,
CT: Roper Center for Public Opinion Research, iPOLL [distributor], accessed April 21, 2015.

446. Harvard School of Public Health, Henry J. Kaiser Family Foundation. Harvard School Of Public Health Survey On Health Care Issues, Sep, 1993 [survey question]. USPSRA.HS1093.R04. Princeton Survey Research Associates [producer]. Storrs, CT: Roper Center for Public Opinion Research, iPOLL [distributor], accessed April 21, 2015 .

447. Henry J. Kaiser Family Foundation, Harvard School of Public Health. Public Knowledge of Health Reform Survey, Sep, 1993 [survey question]. USPSRA.93HLTK.R01. Princeton Survey Research Associates [producer]. Storrs, CT: Roper Center for Public Opinion Research, iPOLL [distributor], accessed April 21, 2015.

448. Families USA, Health Insurance Association of America. Uninsured Americans Survey, Sep, 1999 [survey question]. USPOS.99UNINS.R16. Public Opinion Strategies and [producer]. Storrs, CT: Roper Center for Public Opinion Research, iPOLL [distributor], accessed April 21, 2015.

449. Harvard School of Public Health, Robert Wood Johnson Foundation. Health Insurance Coverage Survey, Jul, 2001 [survey question]. USICR.01CVJL.R33. ICRInternational Communications Research [producer]. Storrs, CT: Roper Center for Public Opinion Research, iPOLL [distributor], accessed April 21, 2015.

450. Henry J. Kaiser Family Foundation. ER Wave One Survey, Sep, 1997 [survey question]. USPSRA.97ERW1.R03. Princeton Survey Research Associates [producer]. Storrs, CT: Roper Center for Public Opinion Research, iPOLL [distributor], accessed April 21, 2015.

451. Henry J. Kaiser Family Foundation. ER Wave Two Survey, Nov, 1997 [survey question]. USP-

SRA.97ERW2.R03. Princeton Survey Research Associates [producer]. Storrs, CT: Roper Center for Public Opinion Research, iPOLL [distributor], accessed April 21, 2015.

452. Henry J. Kaiser Family Foundation, The NewsHour with Jim Lehrer. Kaiser/Newshour Uninsured Survey, Jan, 2000 [survey question]. USICR.00INSR.R03. ICRInternational Communications Research [producer]. Storrs, CT: Roper Center for Public Opinion Research, iPOLL [distributor], accessed April 21, 2015.

453. Gilens, 1999, pp. 49, 127.

454. Henry J. Kaiser Family Foundation, The NewsHour with Jim Lehrer. Kaiser/Newshour Uninsured Survey, Jan, 2000 [survey question]. USICR.00INSR.R03. ICRInternational Communications Research [producer]. Storrs, CT: Roper Center for Public Opinion Research, iPOLL [distributor], accessed April 21, 2015. 


\section{Chattopadhyay}

455. Schneider and Ingram, 1993, p. 339.

456. Ingram and Schneider, 2005a, p. 11, original emphasis.

457. Christopher Cousins, "LePage: Medicaid expansion would add too many smokers and heavy drinkers to program," Bangor Daily News, September 16, 2013, http://bang ordailynews.com/2013/09/16/health/lepage-medicaid-expans ion-would-add-too-many-smokers-and-heavy-drinkers-to-pr ogram/.

458. Robert Long, "Medicaid researcher: LePage missed point of study he used to oppose expansion," Bangor Daily News, September 18, 2013, http://bangordailynews.com/201 3/09/18/health/medicaid-researcher-lepage-missed-point-of-st udy-he-used-to-oppose-expansion/.

459. Oberlander, pp. 43, 165.

460. Campbell, 2003, pp. 85, 95.

461. Soss, pp. 369-372.

462. Campbell, 2003, p. 138.

463. Pierson, 1994, p. 4 [quote]; see also p. 9.

464. Soss, Fording, and Schram.

465. Wilson, p. 478.

466. Mara S. Sidney, "Contested images of race and place: The politics of housing discrimination," in Deserving and Entitled: Social Constructions and Public Policy, Anne L. Schneider and Helen M. Ingram, eds. (New York: State University Press of New York, 2005), pp. 111-137, at p. 137.

467. Quadagno, 1994.

468. Sanford F. Schram, "Putting a black face on welfare: The good and the bad," in Deserving and Entitled: Social Constructions and Public Policy, Anne L. Schneider and Helen M. Ingram, eds. (Albany: State University of New York Press, 2005), pp. 261-286.

469. Soss, Fording, and Schram, p. 64.

470. Neubeck and Cazenave, p. 111.

471. Soss, Fording, and Schram, pp. 63, 300.

472. Quadagno, 1994.

473. Schneider and Ingram, 2005b, p. 108.

474. Schram, p. 284.

475. Neubeck and Cazenave, p. 207.

476. Ann Chih Lin and David R. Harris, "Why is American poverty still colored in the twenty-first century?," in The Colors of Poverty: Why Racial and Ethnic Disparities
Persist, Ann Chih Lin and David R. Harris, eds. (New York: Russell Sage Foundation, 2008), pp. 1-18, at p. 12.

477. Armstrong, Carpenter, and Hojnacki, p. 759.

478. Schram, p. 284.

479. Neubeck and Cazenave, pp. 208, 210.

480. Soss, Fording, and Schram, pp. 59-60.

481. Neckerman, Aponte, and Wilson, p. 401.

482. John A. Powell, "Post-racialism or targeted universalism," Denver University Law Review, 2008, 86: 785-806, at pp. 789, 790.

483. Lin and Harris, p. 4.

484. Marianne Bertrand and Sendhil Mullainathan, "Are Emily and Greg more employable than Lakisha and Jamal? A field experiment on labor market discrimination," The American Economic Review, 2004, 94(4): 991-1013.

485. Soss, Fording, and Schram, pp. 59-60.

486. Neubeck and Cazenave, p. 182.

487. Wilson.

488. Newman, pp. 152, 205-208, 276.

489. DiAlto, p. 81.

490. Winter, p. 405.

491. National Immigration Law Center, "Immigrants and the Affordable Care Act," 2014, http://www.nilc.org/immigr antshcr.html, accessed September 9, 2015.

492. Ono and Sloop, pp. 30, 37, 70-71, 161.

493. Francisco I. Pedraza and Ling Zhu, "Immigration enforcement and the 'chilling effect' on Latino Medicaid enrollment," http://healthpolicyscholars.org/sites/healthp olicyscholars.org/files/pedrazazhu_medicaid.pdf, accessed September 8, 2015, p. 2.

494. Pedraza and Zhu, p. 2.

495. U.S. Department of Health and Human Services, 2014.

496. Pedraza and Zhu, p. 40.

497. Pedraza and Zhu, p. 2.

498. Henry J. Kaiser Family Foundation, "Health coverage for the Hispanic population today under the Affordable Care Act,” April 2013, https://kaiserfamilyfoundation.files.w ordpress.com/2013/04/84321.pdf, p. 4. 


\section{Press depictions of ACA beneficiaries}

499. Ling Zhu and Jennifer Hayes Clark, "Inequality in health care persists at the state level, especially in red states with diverse populations," LSE US Centre blog, May 7, 2015, http://blogs.lse.ac.uk/usappblog/2015/05/07/inequality -in-health-care-persists-at-the-state-level-especially-in-red-sta tes-with-diverse-populations/.

500. Soss, Fording, and Schram, pp. 10, 84, 109, 128, 296.

501. Louise Radnofsky, HHS Secretary says coming sign-up season will be toughest yet under health law," Wall Street Journal, September 22, 2015, http://www.wsj.com/articles/h hs-secretary-says-coming-sign-up-season-will-be-toughest-yet -under-health-law-1442937136.

502. Mettler, 2011, p. 89.

503. Mettler, 2011, p. 30.

504. Ono and Sloop, p. 32.

505. Soss, Fording, and Schram, p. 19.

506. Soss, Fording, and Schram, pp. 23, 51.

507. Mettler, 2011, p. 30.

508. Campbell, 2003, p. 146.

509. Oberlander, pp. 24, 78, 80, 81 .

510. Winter, p. 404.

511. Pierson, 1994, p. 138.

512. Olson, pp. 181-203.

513. Helene Slessarev, "Racial tensions and institutional support: Social programs during a period of retrenchment," in The Politics of Social Policy in the United States, Margaret Weir, Ann Shola Orloff, and Theda Skocpol, eds. (Princeton: Princeton University Press, 1988), pp. 357-379, at p. 377.

514. Shanna Rose, Financing Medicaid: Federalism and the Growth of America's Health Care Safety Net (Ann Arbor: University of Michigan Press, 2013), as cited in Campbell, 2015, p. 284.

515. Pierson, 1994, p. 138 [quote]; see also p. 139.

516. Jacobs, 2010, p. 621.

517. Paul Starr, Remedy and Reaction: The Peculiar American Struggle over Health Care Reform (New Haven: Yale University Press, 2011), pp. 203-205.

518. Jacobs, 2014, p. 637.
519. Pierson, 1994, p. 23.

520. Pierson, 1994, p. 8.

521. Pierson, 1994, p. 97.

522. Mettler, 2011, p. 32.

523. Campbell, 2015, p. 284.

524. Hacker, p. 243 [quote]; see also pp. 245, 249, 252254.

525. Lin and Harris, p. 2.

526. Patashnik and Zelizer, 2013, p. 1079.

527. Wendy K. Mariner, "The Affordable Care Act individual coverage requirement: Ways to frame the commerce clause issue," Annals of Health Law, 2012, 21(1): 45-62.

528. Thomas R. Oliver, "The dilemmas of incrementalism: Logical and political constraints in the design of health insurance reforms," Journal of Policy Analysis and Management, 1999, 18(4): 652-683.

529. Anna Sours, "From Affordable Care Act to 'Obamacare': Political party and the framing of health care in the 2012 presidential election," Science and Social Sciences event, 2013, http://digitalcommons.linfield.edu/studsymp_sci /2013/all/29/, accessed May 9, 2015.

530. Laura S. Hussey and Shanna Pearson-Merkowitz, "The changing role of race in social welfare attitude formation: Partisan divides over undocumented immigrants and social welfare policy," Political Research Quarterly, 2013, 66(3): 572-584.

531. Betsy Leimbigler, "Mixed frames of Obamacare: A critical discourse analysis of the intertwining of rights and market framing discourse surrounding the Patient Protection and Affordable Care Act," (Unpublished master's thesis, Ottawa, ON: University of Ottawa, 2014), http://ruor.uotta wa.ca/handle/10393/31780, accessed May 9, 2015.

532. Hussey and Pearson-Merkowitz, p. 581 n11.

533. Hussey and Pearson-Merkowitz, p. 573, 574.

534. Leimbigler, pp. 22, 26, 37, 39, 40.

535. Leimbigler, pp. 14, 61.

536. Leimbigler, pp. 76, Table 1, 81, Table 2, Table 6, 102, 107.

537. Leimbigler, pp. 73, 74.

538. Leimbigler, p. 2. 


\section{Chattopadhyay}

539. Leimbigler, chapters 3 and 4.

540. Colleen L. Barry, "First impressions: Geographic variation in media messages during the first phase of ACA implementation," Johns Hopkins Bloomberg School of Public Health, June 2014, http://www.academyhealth.org/fil es/2014/monday/barry.pdf, accessed August 3, 2015.

541. Chong and Druckman, 2007a, p. 118.

542. Chong and Druckman, 2007 b, p. 107.

543. Katz, pp. 89, 146.

544. Barbara J. Nelson, "The origins of the two-channel welfare state: Workmen's compensation and mothers' aid," in Women, the State, and Welfare, Linda Gordon, ed. (Madison: University of Wisconsin Press, 1990), pp. 123-151, as cited by Soss, Fording, and Schram, p. 55.

545. Deborah Stone, "Foreword," in Deserving and Entitled: Social Constructions and Public Policy, Anne L. Schneider and Helen M. Ingram, eds. (Albany: State University of New York Press, 2005), pp. ix-xiii, at p. xiii.

546. Campbell, 2003, p. 137.
547. Jacobs and Mettler, p. 917.

548. Jacobs, 2014, p. 638.

549. Chong and Druckman, 2007c, p. 637.

550. Gilens, 1999, pp. 6, 111-112, 138-139.

551. Ben-Porath and Shaker, pp. 470, 471.

552. Mendelberg, 2001.

553. Palmer, 2011b, pp. 5-6.

554. Nelson and Kinder, p. 1074.

555. Lipton and Gay Stolberg.

556. Ashley Parker and Robert Pear, "House approves bill that allows policy renewals," The New York Times, November 16, 2013, http://www.nytimes.com/2013/11/16 /us/politics/obama-to-meet-with-insurance-executives.html, accessed May 4, 2015.

557. Skocpol, 1992, p. 479.

558. Weir, Orloff, and Skocpol, 1988d, pp. 288-289.

559. Ingram and Schneider, 2005a, p. 11. 


\section{Press depictions of ACA beneficiaries}

\section{Appendix}

\section{A detailed explanation of methods}

As noted in the main text, analysis proceeded in three phases. First, the following steps were performed manually to identify portrayals of the newly Medicaideligible and separately of the subsidy-eligible. A human coder searched for sentences containing eligib, expan, tax credit, and subsid in each state's article set using the find function in Word, highlighting the full sentences that did contain any of these elements. The coder (often the same person) then differently highlighted words in those sentences that the coder assessed as describing those newly eligible for Medicaid under the ACA, using instructions provided by the author (available by request). As noted in the main text, this highlighting was to exclude descriptions of beneficiaries joining Medicaid due to the woodwork effect. Highlighting included descriptions of those who would be eligible if their states expanded Medicaid. The coder differently highlighted words in those sentences that the coder saw as describing the subsidy-eligible, again with author-provided guidelines. This highlighting included descriptions of people who would use the exchanges and then find out if they were subsidy-eligible. If the coder did not believe that a sentence highlighted in the first step contained descriptions of the subsidy- or newly Medicaid-eligible and thus added no highlights at the second step, or if the coder judged the article to be virtually identical to another one already in the state's set, no words in the sentence became part of the text data. If a coder believed that a word described both the subsidy- and newly Medicaid-eligible, the coder indicated so, and those words entered the data for both groups. References to national-level information were highlighted, but care was taken-as described later in this paragraph-to ensure that final highlighted material described residents of the state at hand, not of other states. Consequently, when it appears in the data, a term like "Californians" should come from a California article and thus signal an "insider" portrayal in the sense discussed in part III. The author coded (for descriptions of the two groups) articles for ten states, one graduate assistant (A) coded articles for 19 states, and another graduate assistant (B) coded articles for 21 states. ACA exchange and Medicaid decisions were diverse within the states that each person coded at the time the coding was done, taking decisions from May and June 2014 from the Henry J. Kaiser Family Foundation and National Conference of State Legislatures (as cited in the main text and under Table 1) as the reference. (One exception however, is that when coding articles for portrayals of the newly Medicaid-eligible and the subsidy-eligible, assistant $\mathrm{B}$ best followed the instructions to exclude information about residents of states other than the state at hand, or to flag it for me to exclude. I therefore retroactively went through states coded by assistant A, and those coded by myself, to check for, and when necessary to "un-code," coded material that was-from the article text-plainly about residents of other states. While it would have been preferable for graduate assistant A to make these corrections, this student was no longer on the project when this issue was detected. A full report on the material from assistant A that was "un-coded" is available on request; the substantive results for these 19 states taken together differ very little with versus without this material).

Similar steps were taken to identify portrayals of those gaining and, separately, losing insurance. The same 8019 articles were used; coders were given blank versions not containing highlights about the subsidyor newly Medicaid-eligible. For each state, a coder found and highlighted sentences containing any of the following words or phrases: lose, losing, cannot afford, can't afford, for the first time, become insured, will become, will gain, will get, uninsured. The coder, often the same person, then read those sentences and identified and differently highlighted words within them that in his or her assessment described those losing insurance due to the ACA. The coder identified and differently highlighted words in those sentences that in his or her assessment described those gaining insurance under the ACA, including via Medicaid-so long as the person's eligibility for Medicaid was new due to the ACA as far as the coder could judge. Coders were again given instructions to guide these determinations, available by request. Again, if the coder did not believe that a sentence highlighted in the first step contained any such descriptions and thus did not add highlights at this stage, or if the coder judged the article to be the same as another already in the state's set, words from the sentence did not become part of the data. If a coder believed that a word described people who were both losing and gaining insurance due to the ACA, the coder indicated so and those words entered the data for both groups. Material about people in states other than the state at hand was again to be 


\section{Chattopadhyay}

excluded; here, these instructions appear to have been well followed in research assistants' coding. Here, unlike in coding for those newly Medicaid-eligible, descriptions of people who would only be eligible for Medicaid if their (non-expanding) states implemented the expansion were to be excluded. Graduate assistants were instructed to either not highlight this information, or to highlight it but flag it as likely meriting exclusion. If it was so flagged, I excluded it from the data. I coded (the same) ten states for insurance-loser and -gainer portrayals. Graduate assistant B coded 19 states (different from those that this assistant had coded for information about the subsidy- and newly Medicaid-eligible). A third graduate assistant (C) coded five states; a fourth graduate assistant (D) coded 14; a fifth graduate assistant (E) coded two. Further details are available by request.

The next phase involved extracting the highlighted information and transforming it into data. For one state at a time, I manually harvested the items thus coded as describing the newly Medicaid-eligible and saved them in a document for each state, as described in the main text. I likewise harvested the words coded as describing the subsidy-eligible and insurance-losers and -gainers. As noted, the result is four documents for each state: one describes the subsidy-eligible, one the newly Medicaid-eligible, one insurance-losers, one insurance-gainers.

As noted in the main text, I then assembled four corpuses, one consisting of the 50 documents (one per state) describing the newly Medicaid-eligible, a second the 50 describing the subsidy-eligible, a third the 50 describing insurance-gainers, and a fourth the 50 describing insurance-losers. I ran each corpus through basic automated textual processing using the RTextTools and other packages in $\mathbf{R}$ (version 2.15.2), removing white space and converting all words to lower-case. As noted, I did not here reduce words to their roots or remove terms like "the," numbers, and punctuation, in the interest of preserving information relevant to portrayals. For instance, I wanted to be able to separate, if it occurred, "dakota's" from "dakotas," since the former may describe "insiders" in the sense noted in part III, while the latter may simply reference geography. I also wanted to preserve numbers and maximum information about numbers; for instance " $400 \%$ " is likely a reference to those up to 400 percent FPL, while the meaning of " 400 " is less clear. I also wanted to preserve instances of "he" and "she" to track gender in portrayals.
After thus minimally preparing the documents, I used automated methods in $\mathbf{R}$ to generate four DTMs as described in the main text, one consisting of the terms describing the newly Medicaid-eligible, one the terms describing the subsidy-eligible, one the terms describing insurance-gainers, and one the terms describing insurance-losers. I use these DTMs in the third phase of the analysis.

In that phase, each term from the DTMs was manually assigned a "tag." Tags were developed by the author. Tags were motivated by the literature reviewed in part III, and also emerged inductively from consideration of the terms. For instance, "his" was given the tag Male, as were male names such as "jonathan." Personal pronouns such as "i'm" and "your" were given the tag Personal, although "our" was given the tag Strong Insider in the vein of Winter's discussion of "our elderly" as cited in the main text. The author decided which terms received which tags; graduate assistants were not involved in this process.

To sort out which terms belong to which tags, and how often each tag appears, I built "dictionaries," again in the vein of past work on textual analysis as cited in the main text. Dictionary 1, presented in online Appendix 1, contains 40 tags. Dictionary 1 leaves words of a high level of ambiguity untagged, alongside numbers with no clear meaning and generic words such as "people." It tags city and state names simply as Geography. It tags terms like "citizens," "taxypayers," "hoosiers," "yorkers," and "country's" (which, like Winter's "our," is possessive) as Strong Insider. It tags terms like "residents" and "nationwide" as Weak Insider to accommodate the sense that such terms are not so generic as "people," and yet not so embracing as "hoosiers." It codes only explicit probable references to a race or ethnicity other than non-Hispanic White-such as "asian," "black," "hispanic," "indian," and "latino"-as Non White, and tags all surnames simply as Surname regardless of the ethnicity they may suggest. It tags the "working-poor" and terms like "low wage" as Workers. It tags terms like "mother" and "husband" simply as Female and Male.

As noted, I also created five alternative dictionaries to address the fact that many terms can be differently tagged depending on the analyst's interests or willingness to make assumptions. Online Appendix 2 describes these dictionaries in brief. The two of most interest for purposes of the results are Dictionaries 3 and 5 . Dictionary 3 is like Dictionary 1 but makes strong assumptions about numbers; for instance, dollar values 


\section{Press depictions of ACA beneficiaries}

between $\$ 1000$ and $\$ 30,000$ are tagged as General Low Income rather than left untagged. Values of $\$ 30,000$ and above are tagged as Cross-Class. Numbers possibly suggesting ages, like "four" and "seventeen" are tagged as Children while numbers like "57" and "60" are tagged Near Elderly. Dictionary 5 is like Dictionary 1 but tags terms such as "working-poor" and "lowwage" as General Low Income rather than Workers. For brevity, only the results from Dictionary 1 are presented in full, and only Dictionary 1 appears in online Appendix 1. Key results are largely similar across dictionaries. Full results from dictionaries 2 through 6, and the dictionaries themselves, are available on request.

\section{Data check: text sensitivity to database used to find articles}

LexisNexis casts a wide net in the newspapers it archives (see http://w3.nexis.com/sources/scripts/eslClie nt.pl?GSDTYPE=Newspapers\#N), but in a preliminary examination, the articles obtained from LexisNexis only partly overlap those obtained from NewsBank. It may also be that papers not archived in LexisNexis have smaller circulations than those that are archived (see online Appendix 3). As noted in the main text, to check whether the results would have been systematically different had I used a database other than LexisNexis, articles from August 1, 2013, through January 31, 2014, were gathered through NewsBank, using the same key terms, for ten states diverse in region and in ACA Medicaid and exchange decisions: Alabama, Alaska, Arizona, Connecticut, Delaware, Indiana, Maine, Virginia, Washington and Wisconsin. Graduate assistants B (for three states) and C (for seven states) carried out the manual procedures described above to code the resulting articles for portrayals of the subsidy- and newly Medicaid-eligible (details available by request); they were not asked to code for portrayals of insurance-losers or -gainers. Resulting words were then analyzed using the methods described above. As part VI reports, the portrayal results for these ten states as analyzed through NewsBank-based data differ very little from results for the 50 states reported from analysis of LexisNexis-based data. Thus, it does not appear that using LexisNexis to locate articles led to systematically different aggregate results than would have emerged from finding articles through NewsBank.

Two final points merit mention. First, textual analysis can be automated to a greater degree than it is here- see the articles by Grimmer and Stewart and Lucas et al. cited in the main text-but, Grimmer and Stewart note that it is not possible to eliminate human interpretation. Second, the reader may wonder whether the timing with which LexisNexis indexes articles impacts the articles found. Timing should minimally impact the articles returned, since the articles were gathered retroactively, as noted above. 